Article

\title{
Cellular Pharmacology of Palladinum(III) Hematoporphyrin IX Complexes: Solution Stability, Antineoplastic and Apoptogenic Activity, DNA Binding, and Processing of DNA-Adducts
}

\author{
Georgi Momekov ${ }^{1, *}$, Iva Ugrinova ${ }^{2}$, Evdokia Pasheva ${ }^{2}$, Daniela Tsekova ${ }^{3}$ \\ and Galina Gencheva ${ }^{3, *}$ \\ 1 Department of Pharmacology, Pharmacotherapy and Toxicology, Faculty of Pharmacy, \\ Medical University-Sofia, 2 Dunav Str., BG1000 Sofia, Bulgaria \\ 2 Laboratory of Chromatin Structure and Functions, Institute of Molecular Biology, \\ Bulgarian Academy of Sciences, G. Bonchev Str. B1.21, BG1113 Sofia, Bulgaria; \\ ugryiva@gmail.com (I.U.); eva@bio21.bas.bg (E.P.) \\ 3 Department of Analytical Chemistry, Faculty of Chemistry and Pharmacy, Sofia University, \\ 1 J. Bourchier Str., BG1164 Sofia, Bulgaria; dtsekova@chem.uni-sofia.bg \\ * Correspondence: gmomekov@gmail.com (G.M.); ggencheva@chem.uni-sofia.bg (G.G.); \\ Tel.: +359-895776792 (G.M.); +359-877879088 (G.G.)
}

Received: 21 July 2018; Accepted: 12 August 2018; Published: 19 August 2018

\begin{abstract}
Two paramagnetic Pd ${ }^{\mathrm{III}}$ complexes of hematoporphyrin IX ((7,12-bis(1-hydroxyethyl)3,8,13,17-tetramethyl-21H-23H-porphyn-2,18-dipropionic acid), $\mathrm{Hp}$ ), namely a dinuclear one $\left[\mathrm{Pd}_{2}{ }_{2}\left(\mathrm{Hp}_{-3 \mathrm{H}}\right) \mathrm{Cl}_{3}\left(\mathrm{H}_{2} \mathrm{O}\right)_{5}\right] \cdot 2 \mathrm{PdCl}_{2}$, Pd1 and a mononuclear metalloporphyrin type $\left[\mathrm{Pd}^{\mathrm{III}}\left(\mathrm{Hp}_{-2 \mathrm{H}}\right)\right.$ $\left.\mathrm{Cl}\left(\mathrm{H}_{2} \mathrm{O}\right)\right] \cdot \mathrm{H}_{2} \mathrm{O}, \mathbf{P d} 2$ have been synthesized reproducibly and isolated as neutral compounds at different reaction conditions. Their structure and solution stability have been assayed by UV/Vis and EPR spectroscopy. The compounds researched have shown in vitro cell growth inhibitory effects at micromolar concentration against a panel of human tumor cell lines. A DNA fragmentation test in the HL-60 cell line has indicated that Pd1 causes comparable proapoptotic effects with regard to cisplatin but at substantially higher concentrations. Pd1 and cisplatin form intra-strand guanine bis-adducts as the palladium complex is less capable of forming DNA adducts. This demonstrates its cisplatin-dissimilar pharmacological profile. The test for efficient removal of DNA-adducts by the NER synthesis after modification of pBS plasmids with either cisplatin or Pd1 has manifested that the lesions induced by cisplatin are far better recognized and repaired compared those of Pd1. The study on the recognition and binding of the HMGB-1 protein to cisplatin or Pd1 modified DNA probes have shown that HMG proteins are less involved in the palladium agent cytotoxicity.
\end{abstract}

Keywords: palladium(III) complexes; hematoporphyrin IX; antiproliferative activity; DNA binding and repair; HMGB-1 protein; apoptosis

\section{Introduction}

Cisplatin and the clinically accepted platinum drugs have a great importance for the cancer treatment. They have been applied in most anticancer chemotherapeutic regimens [1-4]. Intensive studies in this area date back to the mid-sixties of the 20th century, with Rosenberg's remarkable discovery of the medicinal power of the inorganic coordination compound "nicknamed" cisplatin [1,5-7]. Since then, cisplatin has revolutionized cancer treatment converting the formerly fatal disease, largely curable [8]. Nowadays, cisplatin is still the most successful anticancer drug in the 
world, and is widely used in the treatment of a multitude of different cancers. Still, regardless of the achievements of cisplatin and the related platinum-based drugs—carboplatin-a second generation, and oxaliplatin - third generation, and those of regional use in specific countries, such as nedaplatin, lobaplatin, and heptaplatin, their application is limited [9]. The restrictions are due to their major drawbacks: effectiveness against a limited range of cancers and its intrinsic resistance, development of acquired resistance $[10,11]$, severe side-effects [12,13], and low solubility. Hence, the efforts in the field of antitumor drugs design target introduction of new formulas possessing both a widened spectrum of chemotherapy and an improved clinical profile $[3,4,9,14]$. Intensive research on drug development processes during the past years shows that the invention of universal compounds active against many cancer types is a task difficult to accomplish. The right way is to develop drugs effective against a small group or a subgroup of cancers. Thus, the successful route leading to new efficient drugs inducing a better tumor response in individual patients is to design a pharmacological agent targeting specific abnormalities in particular cancer cells [4].

There are several approaches to develop new metal-based antitumor agents. Historically, the first one follows the correspondence between anticancer activity and the molecular structure of cisplatin $[3,4,15]$. Thus, a variety of cisplatin-similar platinum(II) complexes with different ligands have been synthesized and tested. The numerous results achieved have led to a set of rules for constructing a molecular structure that appeared to be required in order to manifest antitumor activity [7]. According to the rules, the neutral platinum complex with square-planar geometry, containing two cis-am(m)ine carrier ligands (capable of participating in a hydrogen bonding formation) and two cis-coordinated leaving groups $\left(\mathrm{Cl}^{-}\right.$ligands) possesses the necessary structural features for intravenous administration into the blood stream. It is considered that the complex should remain largely unchanged during circulation and after entering the cells a substitution of one or two more labile ligands occurs thereby activating the complex. This requirement underlines the necessity to render the complex inactive during the transport and determines that the ligand exchange rates should be compatible to the rates of cell division processes $[1,16]$. The platinum(II) complexes whose structure follows these rules represent the so-called classical platinum chemotherapeutics. Numerous investigations have been conducted in order to determine the mechanism by which these drugs carry out their anticancer action [17] and most results concerns cisplatin. In general, the main steps cover: cellular uptake by passive diffusion [18] or active transport via the copper transporters CTR1 and CTR2 [19,20]; aquation followed by activation; DNA platination and cellular processing of Pt-DNA lesion leading to apoptosis or to the cell survival. Nuclear DNA is considered the ultimate target of cisplatin and related platinum therapeutics and their capability to form bifunctional DNA crosslinks causing the DNA distortion. Thus, the platinum induced kink in the DNA molecules leads to a chain of events including protein recognition and eventual apoptosis. Unfortunately, some of the platinum compounds can be activated in biological milieu before reaching the tumor cell and they can also interact with nontarget biomolecules. Furthermore, it is clear that DNA is the ultimate pharmacological target of the platinum drugs, but the important issue here is to discern tumor cells from healthy cells. Now it is accepted that the classical platinum compounds can enter in each cell, however the healthy cells and some of the tumor cells can reverse the damage and remove the platinum compounds. Therefore, it is clear that the compounds belonging to this group cannot offer any advantages over cisplatin. Indeed, more than ten other cisplatin related derivatives are currently in clinical trials and the experimental data show $[21,22]$ that they have not overcome considerably many of the disadvantages arising from this common structure. However, the achievement analysis in this field demonstrates that metal coordination compounds can play an important part in anticancer treatment regimes.

Another route to create new metal-based anticancer agents is focused on the mechanism of their antitumor action [23]. In this respect one could distinguish compounds capable of interacting in two different mechanisms: compounds that cause DNA distortion, here including cisplatin- similar and cisplatin dissimilar interactions [3,24-26] and compounds interacting with the key protein targets (including enzymes) that are selective for the specific malignancy and/or that regulate apoptosis, 
and/or that are responsible for cell invasion and metastasis [27,28]. The classical approach based on cell viability assay and characterization of the compounds that bind to DNA and adducts formed has been applied for more than forty years and now this is the first stage for evaluation. Nowadays, the drug design concepts are based on one side on the chemical nature of the compounds and on the other side- on the cancer cells biochemistry. Thus, the new strategies for design and synthesis result in the development of new classes of antitumor agents, the so called "classical nonplatinum metal compounds" and "nonclassical metal compounds" [3] and thus several compounds (e.g., NKP-1339 [29], NAMI-A [30], Satraplatin [31], etc.) are proposed that are on the "verge" of clinical application. These strategies are consistent with requirements for: a comparatively soluble prodrug's form; existence of an inactivated form in the blood stream; selective cellular uptake; activation of the drug form in the tumor cells; appropriate tumor cell damage.

Metal coordination compounds with their inherent properties can meet these requirements to a great extent. Their specific three-dimensional structures combined with suitable electronic and ligand exchange properties are attractive for the creation of a successful formula [3,4]. The transition series metal complexes having variable oxidation states and coordination numbers, and the ability to bind, of different strength, to a wide variety of donor functional groups are some of the most tested compounds. A special attention is paid to the metals from second and third transition series. They usually exchange their ligands slowly, on the same time scale as the cell division processes. Their comparatively inert behavior keeps them as prodrugs, which have to be activated by ligand substitution reaction in the cells. In general, from a chemical point of view, the successful drug should be a well soluble compound with lipophilicity and acid-base properties determining a selective uptake. The drug should be activated inside the tumor cells and attack the target molecules by ligand substitution reactions. It is necessary to interact predominantly with target molecules and the formed adducts should be stable enough in order to provoke proper cell death. It means that a key element in the design processes is the control on the kinetics of ligand substitution reactions in vivo and the thermodynamic stability of the initial, intermediate, and final complexes produced during the antitumor action. In addition, the redox properties determined in terms of both metal and ligand are of special interest. As a part of antitumor mechanism, the change of the metal oxidation state can trigger ligand release and the participation of the ligands in in vivo redox reactions could produce reactive oxygen species. Also, the possibility to achieve light-triggered activation of an excited-state of the metal complexes in tumor cells instead of their ground-state gives additional advantages in the drugs design. All these considerations give the reason to conclude that a properly selected metal ion with regard to its nature, oxidation state, and coordination polyhedron with right ligands in the inner coordination sphere can create a drug able to overcome some of cisplatin's disadvantages.

Recently, a series of hematoporphyrin IX (7,12-bis(1-hydroxyethyl)-3,8,13,17-tetramethyl-21H-23Hporphyn-2,18-dipropionic acid, Hp) complexes [32-39] of platinum, palladium, and gold (Scheme 1) have been tested as tumor growth inhibitors. Hematoporphyrin IX and its derivatives are well known for their widespread application in the photodynamic therapy and diagnosis [40]. It is considered that, due to their acid-base and hydrophobic properties, the porphyrins could preferably accumulate in the neoplastic tissues [41-43]. In fact the selective uptake of porphyrins in malignant tissue cells is due to complex mechanisms, the most important of them being the LDL-receptor mediated endocytosis of porphyrin-lipoprotein complexes formed in the systemic circulation [40].

A new strategy for cytotoxic agents design with improved properties has been proposed in our group, based on the capabilities of this ligand to stabilize unusual oxidation states of the metals. Thus, three $\mathrm{Pt}^{\mathrm{III}}\left(\mathrm{d}^{7}\right)$ [32,33], two Pd ${ }^{\mathrm{III}}\left(\mathrm{d}^{7}\right)$ [34], and one $\mathrm{Au}^{\mathrm{II}}\left(\mathrm{d}^{9}\right)[35,36]$ complexes of Hp were obtained and characterized. The metal ions in the complexes have distorted octahedral coordination. Because of the metals' electronic configuration, the complexes manifest paramagnetic behavior. Further they show comparatively high cytotoxicity in in vitro tests against a panel of human cell lines [32-34,36]. Great efforts have been made in order to understand the effect of the ligand coordination to the antitumor behavior of the complexes. The ligand $\mathrm{Hp}$ has a polydentate nature. Three different modes 
of coordination have been established [37] studying its interaction with metal ions representatives of first [38,39], second [34], and third transition series [32,33,35,36]. Coordination via the four pyrrole $\mathrm{N}$-atoms in the porphyrin framework and forming of metalloporphyrin-type complexes is the most widespread mode of binding, typical of all metal ions under investigation. Coordination via two $\mathrm{N}$-atoms of adjacent pyrrole rings to the metal ions in cis-position leads to the so called "sitting atop" type complexes (SAT). Coordination via the side chains deprotonated propionic $\mathrm{COO}^{-}$groups, outside the porphyrin macrocycle is a less common mode of coordination. The nitrogen donor atoms of the imino $(>\mathrm{N})$ and aza $(=\mathrm{N}-)$ groups of the pyrrole rings, as well as the outside $\mathrm{COO}^{-}$groups determine the nature and the size of three different coordination modes. The metal ions choose a different mode of coordination as a function of their nature and properties.
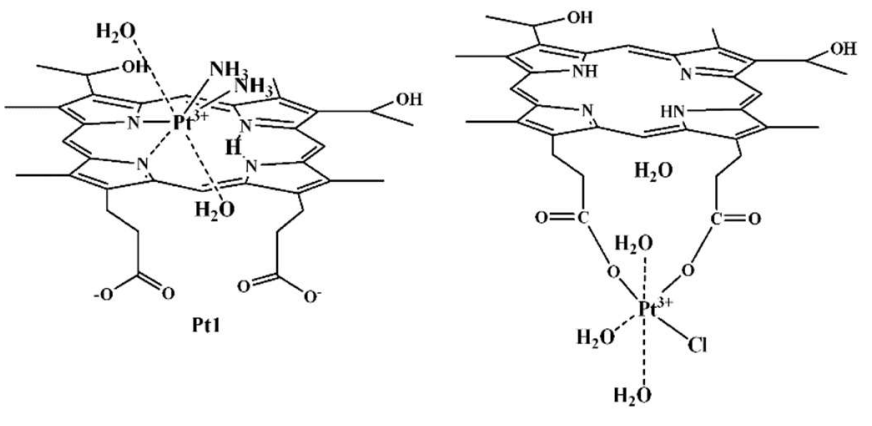

$\mathrm{Pt} 3$

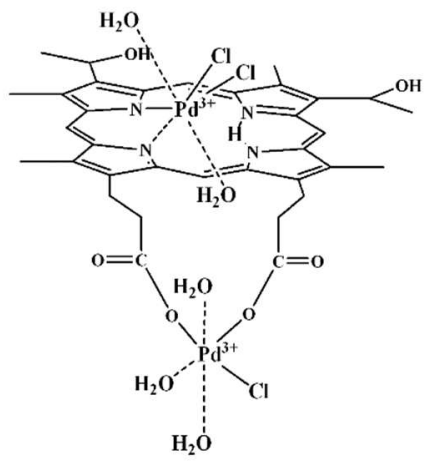

Pd1

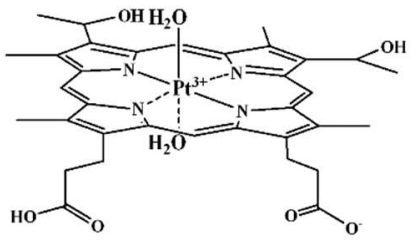

Pt2

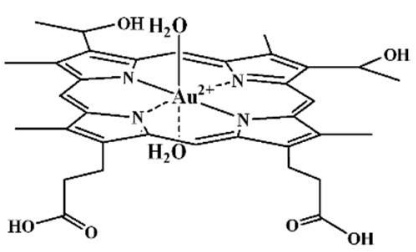

Au 1

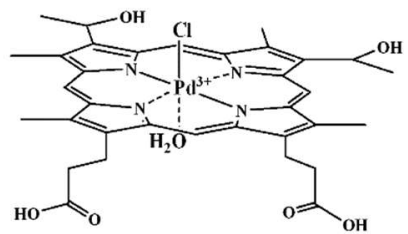

Pd2

Scheme 1. Structures of the hematoporphyrin IX complexes of platinum(III), gold(II) and palladium(III).

Due to its intrinsic inertness, $\mathrm{Pt}$ III forms stable complexes with the three different modes of $\mathrm{Hp}$ coordination (Scheme 1) in the proper reaction conditions [32]. All these complexes with distinct coordination patterns exert concentration dependent antiproliferative activity against a spectrum of cell lines representing some important types of neoplastic diseases in humans. They have also proven to be far less cytotoxic against the human embryonal kidney cell line HEK-293T compared to cisplatin. It has been discovered that the "sitting atop" complex Pt1, with $\mathrm{PtN}_{4}$ coordination plane formed by two adjacent porphyrin pyrrole nitrogens and two $\mathrm{NH}_{3}$-molecules in cis-position as well as the metalloporphyrin-type complex Pt2 possess higher potency compared to $\mathbf{P t} 3$. In the latter, $\mathrm{Pt}^{\mathrm{III}}$ is coordinated to the deprotonated propionic carboxylic groups from the side chains of hematoporphyrin IX. The better solubility of Pt2 compared to Pt1 makes it preferable in research. Thus, its characteristics, such as superior proapoptotic activity that strongly correlates with its cytotoxicity and significantly higher degree of accumulation in tumor cells compared to the reference drug cisplatin, make it a reliable representative of the group of the "metal-based drugs that break the rules" [4].

Another promising representative of this group of compounds is the octahedral gold(II) $\left(\mathrm{d}^{9}\right)$ complex of hematoporphyrin IX, Au1 [35] that is structurally similar to Pt2. The comparison of its cytotoxicity to that of $\mathbf{P t} 2$ manifests that the $\mathrm{Au}^{\mathrm{II}}$ complex exerts superior activity exactly against the 
T-cell leukaemia SKW3. These data correlate well with the estimated specific inhibiting effect of gold species upon immune cells and T-cells [36]. Nevertheless, the compound exerts well-pronounced proapoptotic properties against malignant cells and it is less cytotoxic than cisplatin for the human kidney. Furthermore, this compound demonstrated significant intracellular accumulation presumably mediated by formation of FCS-lipoprotein complexes and subsequent endocytosis.

Two relatively new members of this group compounds are the $\mathrm{Pd}^{\mathrm{III}}\left(\mathrm{d}^{7}\right)$ coordination compounds of hematoporphyrin IX [34]. The dinuclear $\left[\mathrm{Pd}^{\mathrm{III}}{ }_{2}\left(\mathrm{Hp}_{-3 \mathrm{H}}\right) \mathrm{Cl}_{3}\left(\mathrm{H}_{2} \mathrm{O}\right)_{5}\right] \cdot 2 \mathrm{PdCl}_{2}, \mathbf{P d} 1$ and mononuclear $\left[\mathrm{Pd}^{\mathrm{III}}\left(\mathrm{Hp}_{-2 \mathrm{H}}\right) \mathrm{Cl}\left(\mathrm{H}_{2} \mathrm{O}\right)\right] \cdot \mathrm{H}_{2} \mathrm{O}, \mathbf{P d} 2$ have been obtained during the interaction of the ligand with $\mathrm{Pd}^{\mathrm{II}} \mathrm{Cl}_{4}{ }^{2-}$ in alkaline-aqueous medium. In the dinuclear complex, Pd1, one of the $\mathrm{Pd}^{\mathrm{III}}$ ions is coordinated to the deprotanated $\mathrm{COO}^{-}$groups from the side chains of the porphyrin ligand and the second $\mathrm{Pd}^{\mathrm{III}}$ ion-to two adjacent pyrrole $\mathrm{N}$-atoms on the top of the porphyrin ring. The compound is spontaneously obtained at a large metal excess from the reaction in alkaline-aqueous medium. It is accepted that because of the greater kinetic lability of $\mathrm{Pd}^{\mathrm{III}}$ compared to $\mathrm{Pt}^{\mathrm{III}}$ both places for coordination are occupied simultaneously and thus a dinuclear $\mathrm{Pd}^{\mathrm{III}}-\mathrm{Hp}-\mathrm{Pd}{ }^{\mathrm{III}}$ system is formed. The Pd ${ }^{\mathrm{III}}$ ion in the mononuclear complex, Pd2 is incorporated in the porphyrin core. The Pd ${ }^{\mathrm{III}}$ centers in both complexes have a distorted octahedral coordination filled with additional donor species such as $\mathrm{Cl}^{-}$and $\mathrm{H}_{2} \mathrm{O}$.

As a member of the platinum group metals, palladium, with its coordination compounds, is also extensively tested for antitumor activity [44-47]. Because of lanthanoid contraction, both metals palladium and platinum in oxidation state +2 have close ionic radii. They adopt a square-planar geometry and behave like soft acids, forming strong bonds with nitrogen and sulfur-containing ligands [48]. While the equilibrium constants, characterizing the stability of their isostructural complexes differ slightly (only about ten times higher for $\mathrm{Pt}^{\mathrm{II}}$ complexes), their kinetic behavior with respect of the ligand substitution is completely dissimilar as a consequence of the lower electron density of $\mathrm{Pd}^{\mathrm{II}}$. The complexes of $\mathrm{Pd}^{\mathrm{II}}$ simple analogues of $\mathrm{Pt}^{\mathrm{II}}$-antitumor drugs undergo aquation and ligand exchange reaction $10^{4}$ to $10^{5}$ times more rapidly. The fast hydrolysis of the leaving groups leads to the formation of very reactive $\mathrm{Pd}^{\mathrm{II}}$-aquated-species, unable to reach their pharmacological targets as active compounds. It is accepted that the toxic side effects are a result of inactivation of certain enzymes due to binding to the thiol groups of cysteine residues and obviously the much higher reaction rates typical of $\mathrm{Pd}^{\mathrm{II}}$ compounds are favorable for general toxicity.

In order to tune the kinetic behavior and thermodynamic stability of the new compounds proposed as antitumor agents different approaches can be applied. Here, beside the construction of special coordination polyhedra, the intermediate oxidation state +3 of palladium centers has been applied as a factor of great importance. The less common oxidation state of palladium +3 provides many advantages of its complexes, such as a controlled delay of the ligand substitution reactions and reactivity, an octahedral geometry with axial ligands that could alter the redox potential and lipophilicity. The promising antiproliferative activity in micromolar concentration range that has been shown by the Pd ${ }^{\mathrm{III}}$-Hp complexes [34] together with the remarkable cytotoxicity against the K-562 cells with more than 4 fold lower $\mathrm{IC}_{50}$ value compared to cisplatin, characteristic for the dinuclear compound Pd1, is the basis for further detailed biological investigation on the mechanism of action of these new proposed cisplatin-dissimilar agents.

\section{Results}

\subsection{Synthesis and Characterization in Solution}

The Pd ${ }^{\mathrm{III}}$-complexes that undergo extensive biological screening have been obtained from the interaction of the initial palladium(II) salt $\left(\left[\mathrm{Pd}^{\mathrm{II}} \mathrm{Cl}_{4}{ }^{2-}\right]\right)$ and hematoporphyrin IX. The coordination reaction proceeds in alkaline-aqueous medium on air. The ligand used for the syntheses is dissolved in $5 \times 10^{-2} \mathrm{M} \mathrm{KOH}$ solution. The initial acidity of the reaction system has been adjusted within the range of $\mathrm{pH}$ values from 11.2 to 11.5 (by adding $\mathrm{KOH}$ ). The reactions always start by spontaneous 
increase of the reaction acidity $(\Delta \mathrm{pH}=3-4)$ within 3 to $4 \mathrm{~h}$. The creation of paramagnetic complex species during the interaction has been followed by the EPR method. The EPR spectra were registered of samples taken from the reaction systems and frozen. A very wide signal ( $\Delta \mathrm{Hpp} \sim 250 \mathrm{G}$ ) with $\mathrm{g} \sim 2.12$ has been observed in the EPR spectrum of the 1:1 molar ratio reaction system during the first few hours. Further, the interaction continues with appearance of two different signals of variable intensities (Figure 1a): a narrow signal $(\Delta \mathrm{Hpp}=7.2 \mathrm{G})$ with $\mathrm{g}=2.000$, typical for a radical formation and a wide low-intensive signal $(\Delta \mathrm{Hpp} \sim 45 \mathrm{G})$ with $\mathrm{g} \sim 2.06$ without a hyperfine structure. Two days later, together with a radical's singlet, an additional third signal was observed with increasing intensity displaying a hyperfine structure. The final spectrum registered (Figure 1b) consists mainly of two signals: a singlet with parameters proving the presence of a stable radical overlaying a signal of two-component axial anisotropy and principal values of the g-tensor determined by the experiment as $\mathrm{g}_{\perp}=2.037$ and $\mathrm{g}_{\mathrm{II}}=1.979$. The parameters measured for the superhyperfine coupling tensor are $\mathrm{a}_{\perp}=17.8 \times 10^{-4} \mathrm{~cm}^{-1}$ and $\mathrm{a}_{\mathrm{II}}=14.8 \times 10^{-4} \mathrm{~cm}^{-1}$.
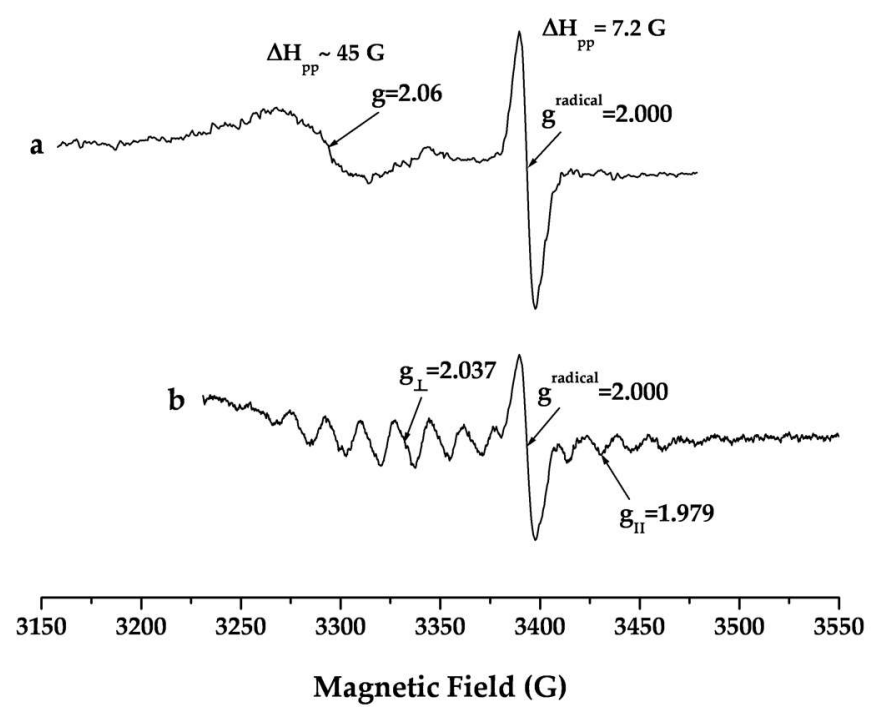

Figure 1. X-band EPR spectra of frozen solutions of the reaction system Pd:Hp = 1 (130 K): (a) a day from the beginning of the reaction; (b) a week later (operating frequency $9.500 \mathrm{GHz}$ ).

The spectral changes in the electronic-absorption spectra during the interaction in alkalineaqueous medium refer to the bands of the free ligand spectrum as follows [49]: an intensive band belonging to a transition $\mathrm{S}_{0} \Rightarrow \mathrm{S}_{2}$ at $376 \mathrm{~nm}$ (B or Soret) and four Q-bands at 505, 540, 567, and $621 \mathrm{~nm}$ from the transitions to nondegenerated orbitals of the first exited state $S_{1}$, with intensities IV > III > II > I, typical of etio-type porphyrins. Two separate stages during the interaction can be distinguished. A slight hypsochromic shift of the Soret band has been observed in the beginning followed by a decrease of its intensity, widening, and a batochromic shift by $\sim 15 \mathrm{~nm}$. During this period of the reaction, the four Q-bands have been shifted batochromically. They have changed their intensities as IV $>$ III $\sim$ II $>$ I and have reduced to three $(\sim 516,558$, and 620sh $\mathrm{nm})$ several hours later with intensities: III $\sim$ II $>$ I. The UV/Vis spectra measured in the second stage of the interaction have been characterized by the Soret band at $390 \mathrm{~nm}$ and two Q-bands at 520 and $559 \mathrm{~nm}$; the long-wave one being the more intensive. Regardless of the metal-to-ligand ratios, in the final spectrum of the interaction, the Q-bands have always reduced to two.

The reaction has been directed to obtaining the particular Pd ${ }^{\mathrm{III}}$-complexes as neutral compounds at different metal-to-ligand ratios. The electronic absorption spectra of the reaction systems before the isolation of the complexes are presented on Figure 2. 


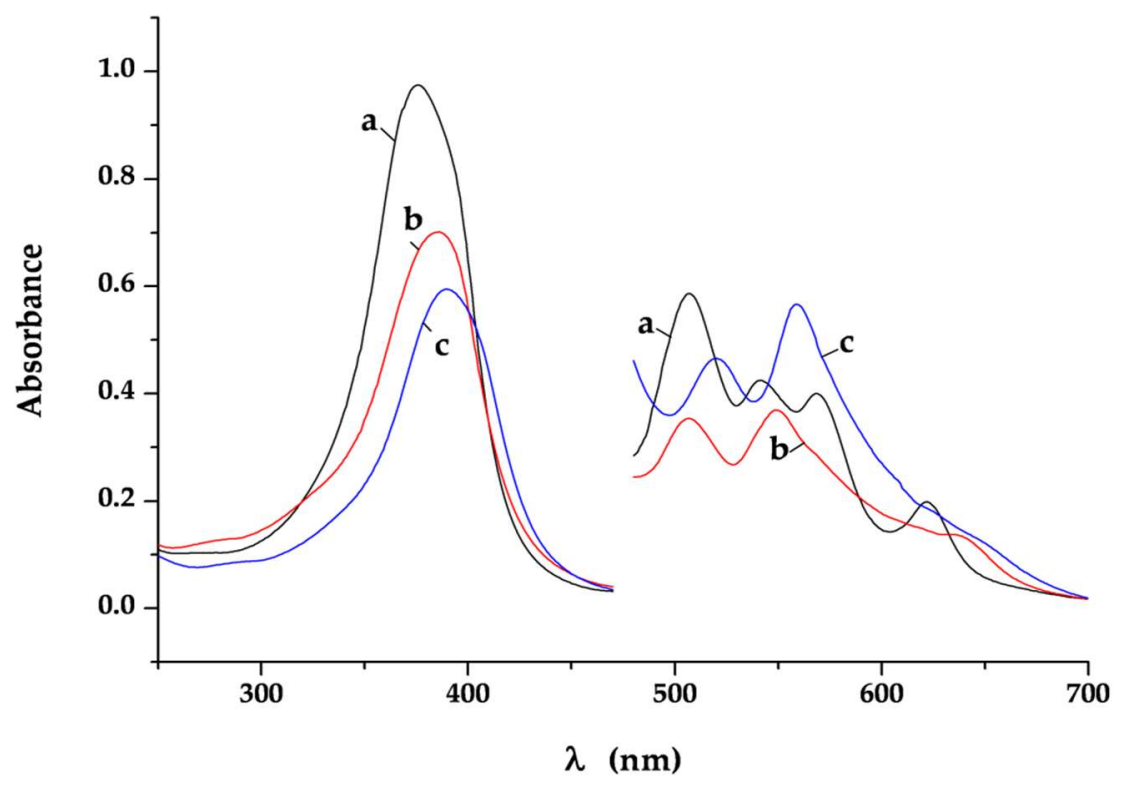

Figure 2. Electronic absorption spectra of: (a) Hp; (b) reaction system $\mathrm{Pd}: \mathrm{Hp}=4$ before isolating complex Pd1; (c) reaction system 1:1 before isolating complex Pd2.

A dinuclear Pd ${ }^{\mathrm{III}}$ complex with a composition $\left[\mathrm{Pd}_{2}^{\mathrm{III}}\left(\mathrm{Hp}_{-3 \mathrm{H}}\right) \mathrm{Cl}_{3}\left(\mathrm{H}_{2} \mathrm{O}\right)_{5}\right] \cdot 2 \mathrm{PdCl}_{2}$, Pd1 is the main product of the interaction at a metal excess ( $\mathrm{Pd}: \mathrm{Hp} \geq 4$ ). The compound was separated spontaneously from the reaction system with coprecipitated 2 molecules of the initial $\mathrm{PdCl}_{2}$ at $\mathrm{pH} \sim 8$. A mononuclear complex with a composition $\left[\mathrm{Pd}^{\mathrm{III}}\left(\mathrm{Hp}_{-2 \mathrm{H}}\right) \mathrm{Cl}\left(\mathrm{H}_{2} \mathrm{O}\right)\right] \cdot \mathrm{H}_{2} \mathrm{O}$, $\mathbf{P d 2}$, was the main product from the interaction at equimolar ratio of the reagents or a slight excess of one of the reagents. The compound was isolated as a neutral one by addition of hydrochloric acid $\left(5 \times 10^{-2} \mathrm{M} \mathrm{HCl}\right)$. The solid-state structure of the complexes and the mode of ligand coordination were studied in detail using magnetic measurements, EPR spectra, thermal and elemental analyses, and IR and UV/Vis spectroscopy [34].

The EPR and UV/Vis spectra were also used to characterize the solution-structure of the complexes and to assay their stability. Both complexes are slightly soluble in water and their solubility is $\mathrm{pH}$ dependent. Moderate solubility was achieved by increasing the $\mathrm{pH}$ value with $\mathrm{KOH}$ or using solvents such as DMSO (dimethyl sulfoxide) or DMF ( $N, N$-dimethyl formamide). In the UV/Vis spectrum of hematoporphyrin IX recorded in DMSO, the Soret band $(400 \mathrm{~nm}, \lg \varepsilon=5.02)$ with a shoulder (376sh, $\lg \varepsilon=4.89)$ and the four Q-bands $(502 \mathrm{~nm}, \lg \varepsilon=3.77 ; 536 \mathrm{~nm}, \lg \varepsilon=3.61 ; 572 \mathrm{~nm}, \lg \varepsilon=3.84 ; 623 \mathrm{~nm}$, $\lg \varepsilon=3.17$ ) can be readily distinguished (Figure 3a). The UV/Vis spectra of DMSO solutions of the complexes display the characteristic three component (for Pd1: $507 \mathrm{~nm}(\lg \varepsilon=3.68), 546 \mathrm{~nm}(\lg \varepsilon=3.68)$, $567 \mathrm{~nm}(\lg \varepsilon=3.63))$ and two component (for Pd2: $512 \mathrm{~nm}(\lg \varepsilon=3.58), 548(\lg \varepsilon=3.74))$ pattern in the region of Q-bands (Figure 3b,c).

The EPR spectrum of the DMSO solution of the complex Pd1 (Figure 4a) contains more than two signals. Two of them possess axial symmetry with principal values of g-tensors, respectively for the first: $g_{\perp}=2.057$ and $g_{I I}=2.496$ with readily observed superhyperfine structure in perpendicular region $\left(\mathrm{a}=15.31 \times 10^{-4} \mathrm{~cm}^{-1}\right)$ and for the second $-\mathrm{g}_{\perp}=2.029$ and $\mathrm{g}_{\mathrm{II}}=2.354$. The wide signal at $\sim 3050 \mathrm{G}$ was assigned to an exchange interaction of two paramagnetic centers in the molecule. In addition, a low intensive signal with $g=1.990$ and $H_{p p}=8 \mathrm{G}$ was assigned to a stable radical. The EPR spectrum of the complex Pd2 dissolved in DMSO (Figure 4b) shows only a signal with two-component axial anisotropy and principal values of the g-tensor measured from the experiment as $g_{\perp}=2.038$ and $g_{I I}=1.979$. The superhyperfine structure measured from the experimental spectrum is well resolved both in perpendicular and parallel regions. The determined principal values of the axial superhyperfine coupling tensor are $\mathrm{a}_{\perp}=16.65 \times 10^{-4} \mathrm{~cm}^{-1}$ and $\mathrm{a}_{\mathrm{II}}=13.85 \times 10^{-4} \mathrm{~cm}^{-1}$. 


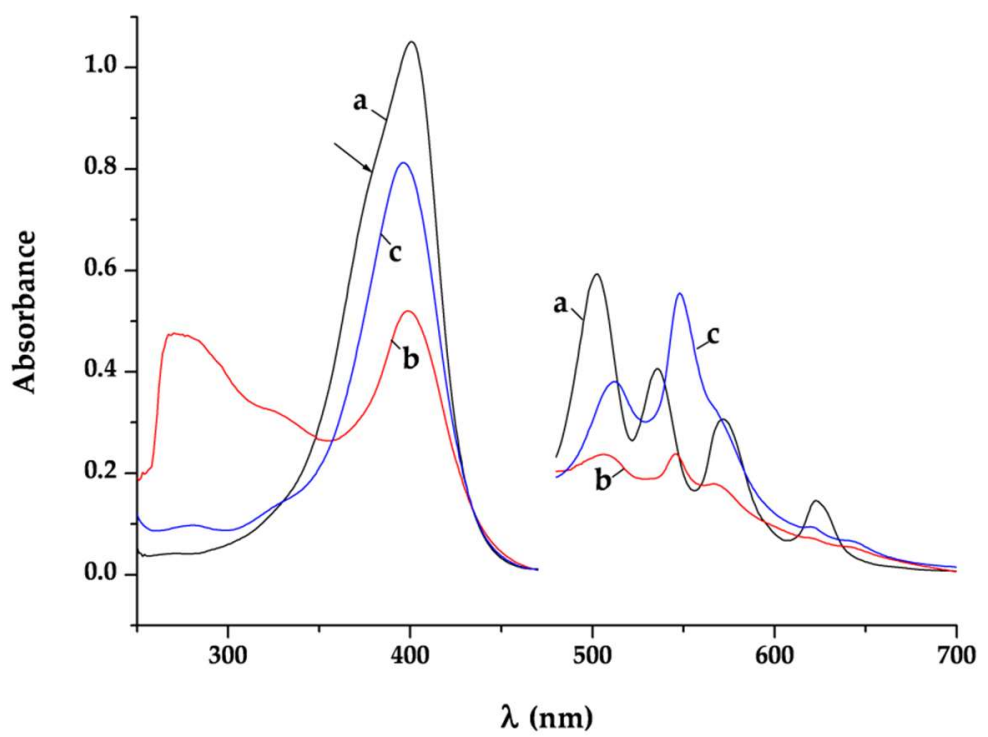

Figure 3. Electronic absorption spectra of Hp and its complexes dissolved in DMSO: (a) Hp; (b) complex Pd1; (c) complex Pd2.

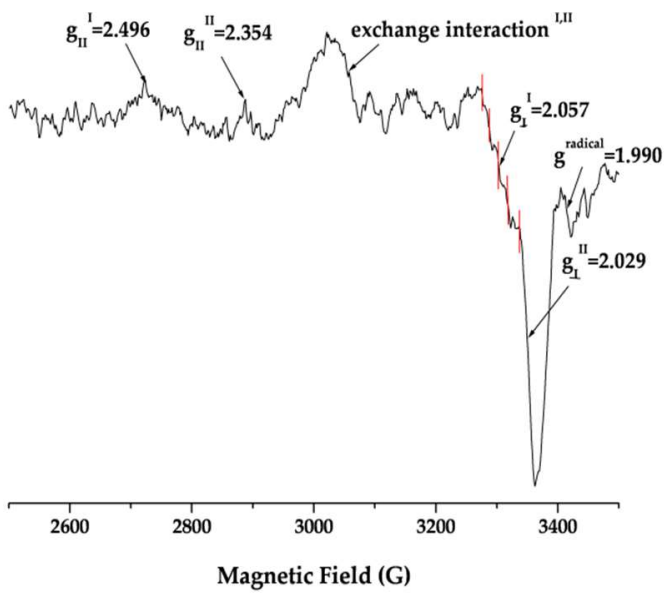

(a)

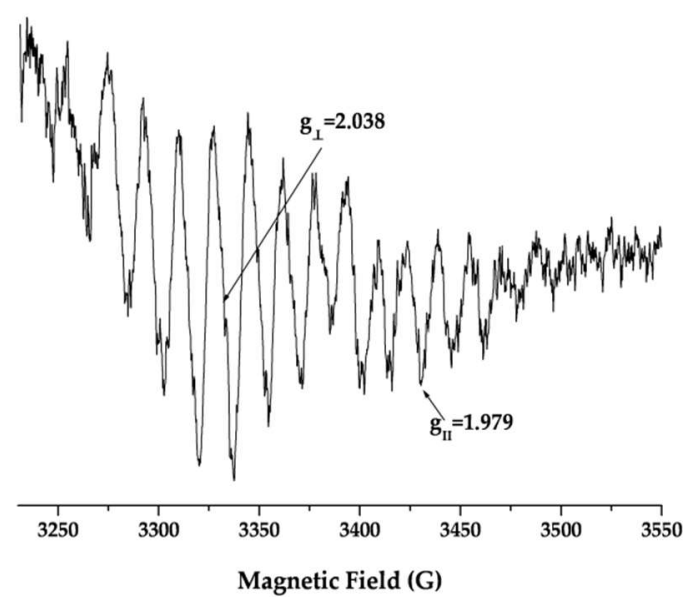

(b)

Figure 4. X-band EPR spectra of Hp complexes dissolved in DMSO, frozen solutions at 130 K (a) Pd1, operating frequency $9.513 \mathrm{GHz}$ (b) Pd2, operating frequency $9.502 \mathrm{GHz}$.

\subsection{In Vitro Tumor Cell Growth Inhibition}

The cell growth inhibitory effects of the complexes subjected to detailed biological screening were evaluated in a panel of human tumor cell lines with distinct cell type and origin in order to determine the most sensitive class of cell lines. The cytotoxicity was assessed using standard MTT-dye reduction assay $[50,51]$. The pilot studies covered the cell lines: SKW-3 (T-cell leukemia), LAMA-84 and K-562 cells (chronic myeloid leukemia), and 5637 (urinary bladder cancer) and the data were published in a previous research [34]. In addition, several leukemic and solid cell lines have been explored, namely: HL-60 (Acute myeloid leukemia), HD-MY-Z (Hodgkin-lymphoma), EJ (Urinary bladder carcinoma), and MCF-7 (Mammary gland carcinoma). The tested compounds inhibited the growth of tumor cells in a concentration-dependent manner. The $\mathrm{IC}_{50}$ values were calculated using nonlinear regression analysis and are summarized in Table 1 . Normally, the tested palladium compounds exert lower activity compared to that of the referent drug cisplatin. The results showed also that as a rule the dinuclear complex Pd1 demonstrated superior activity in contrast to the metalloporphyrin type 
complex Pd2 (Table 1). Furthermore, it should be underlined, that Pd1 exerts remarkable activity against K-562 cells, as the compound tested caused 50\% cell growth inhibition at more than 4 -fold lower concentration with regard to the reference agent [34]. Noteworthy, its activity against the HD-MY-Z cell line is comparable to that of cisplatin.

Table 1. Comparative antiproliferative activity of the investigated palladium complexes (Pd1 and Pd2) and cisplatin in a panel of tumor cell lines after $72 \mathrm{~h}$ continuous exposure (MTT-dye reduction assay).

\begin{tabular}{ccccc}
\hline \multirow{2}{*}{ Cell Line } & Cell Type & \multicolumn{3}{c}{ IC $_{\mathbf{5 0}}(\boldsymbol{\mu M})^{\mathbf{1}}$} \\
\cline { 3 - 5 } & & Pd1 & Pd2 & Cisplatin \\
\hline SKW-3 $^{2}$ & T-cell leukemia & $34.4 \pm 2.2$ & $77.9 \pm 5.1$ & $10.1 \pm 1.4$ \\
K-562 $^{2}$ & Chronic myeloid leukemia & $2.1 \pm 0.9$ & $31.9 \pm 4.3$ & $9.4 \pm 2.1$ \\
LAMA-84 $^{2}$ & Chronic myeloid leukemia & $40.0 \pm 3.4$ & $94.0 \pm 6.2$ & $18.3 \pm 2.6$ \\
HL-60 & Acute myeloid leukemia & $75.2 \pm 2.9$ & $>200$ & $8.2 \pm 1.9$ \\
HD-MY-Z & Hodgkin-lymphoma & $14.1 \pm 4.5$ & $>200$ & $10.2 \pm 3.4$ \\
5637 & Urinary bladder carcinoma & $96.0 \pm 1.1$ & $177.2 \pm 10.2$ & $4.4 \pm 1.7$ \\
EJ & Urinary bladder carcinoma & $117.2 \pm 6.9$ & $>200$ & $9.3 \pm 1.8$ \\
MCF-7 & Mammary gland carcinoma & $79.4 \pm 4.2$ & $>200$ & $6.5 \pm 1.1$ \\
\hline
\end{tabular}

${ }^{1}$ Arithmetic mean \pm standard deviation of at least eight independent experiments. ${ }^{2}$ Data have been published in [34].

\subsection{Induction of Apoptosis}

The ability of the palladium complexes to induce programmed cell death was evaluated using the more active complex Pd1 compared to cisplatin in HL-60 cells. The assessment has been made with a commercially available DNA-fragmentation kit allowing semi-quantitative determination of the degree of oligonucleosomal genomic DNA fragmentation. The results concerning the HL-60 cell line (Figure 5) proved that both, Pd1 and cisplatin cause significant increase in the apoptotic histone-associated DNA fragments, but the comparison of their behavior shows that the novel dinuclear compound causes comparable proapoptotic effects at substantially higher concentrations, which is in line with the tumor cell line chemosensitivity bioassay (Figure 5).

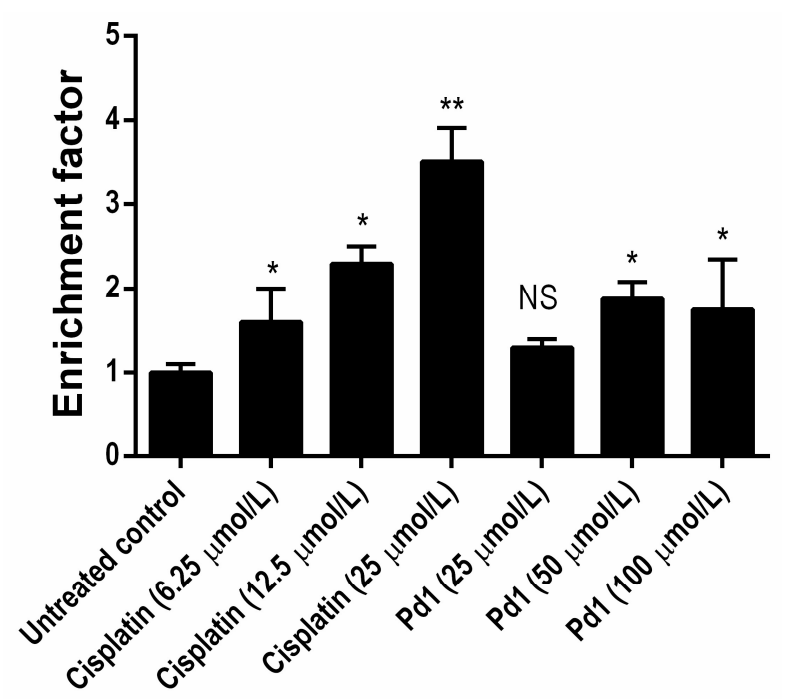

Figure 5. Apoptotic DNA-fragmentation in HL-60 cells after 24 h exposure to complex Pd1 and cisplatin. The cytosolic mono- and oligo-nucleosomzal enrichment was determined using a commercially available ELISA kit. Each bar is representative for three independent experiments. Asterisks indicate statistical significance vs. the untreated control with $p \leq 0.05\left(^{*}\right)$ or $p \leq 0.01\left({ }^{* *}\right)$ taken as significance levels; NS = non-significant (paired Student's $t$-test). 


\subsection{DNA-Modification}

In order to evaluate in parallel the ability of Pd1 and cisplatin to form intra-strand guanine bis-adducts, we investigated their binding to a synthetic 40-base DNA fragment bearing a single GG sequence [52]. Optimal binding to the target DNA molecule was observed at molar ratio 1:50 for cisplatin and molar ratio 1:100 for Pd1, respectively, after overnight incubation (Figure 6). Cisplatin treatment led to a total inhibition of the BamH1-mediated fragmentation of the DNA-probe indicating a high metallation ability. The dinuclear palladium complex Pd1 also inhibited the nuclease activity as is evident by the low quantity of digested fragment but failed in the totally hamper the fragmentation of the target DNA-molecule.

\section{CB cis cisB Pd PdIB PdIIB}

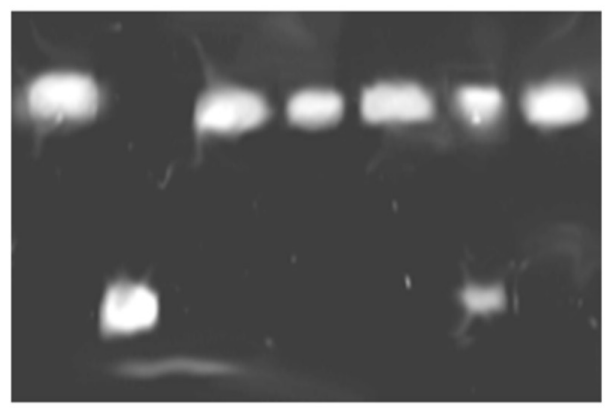

Figure 6. Metallation of a 40-base DNA fragment following treatment with cisplatin (molar ratio 1:50) and Pd1 (molar ratios 1:100 and 1:200). The level of metal binding following interactions between the tested complexes and the DNA probe was analyzed after BamH1 treatment, electrophoretic analysis in $5 \%$ native polyacrilamide gel, and ethidium bromide staining. On the picture: $C$, unmodified DNA; CB, BamH1-digested DNA; cis, cisplatin-modified DNA; cisB, cisplatin-modified DNA (1:50) BamH1-digested; Pd, Pd1-modified DNA; PdIB, Pd1-modified DNA (1:100) BamH1-digested, PdIIB, Pd1-modified DNA (1:200) BamH1-digested.

\subsection{DNA-Repair Synthesis}

The elucidation of the cellular processing of metallodrug-induced DNA-adducts is of crucial importance for delineation of the pharmacological behavior of the antitumor agents $[53,54]$. The results of the DNA-repair experiments run under optimal conditions: plasmid:drug ratios 1:750, overnight are shown on Figure 7. The adducts induced by cisplatin or Pd1 treatment were recognized and efficiently repaired by the nucleotide excision repair (NER) enzymes. It was found that the level of DNA-repair of pBS plasmid after treatment with Pd1 was far less efficient than that encountered by the cisplatin-modified DNA probe. These findings indicate that the Pd1 would have advantageous behavior against tumor cells, characterized by an overexpression of the NER-enzymatic machinery, mediating one of the most important mechanisms of post-target resistance to platinum drugs. 


\section{Contr. Cisplatin Pd1}
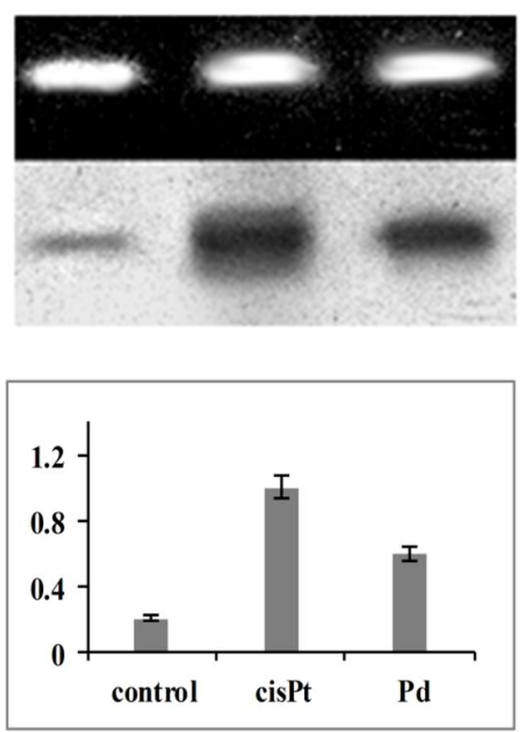

Figure 7. Relative efficiency of the nucleotide excision repair process in pBS plasmids modified by treatment with cisplatin or Pd1 (plasmid:drug ratio 1:750, overnight). Repair of cisplatin-modified pBS is set as 1 .

\subsection{HMGB-1 Binding to Pd1 or Cisplatin-Modified DNA}

The ability of high mobility group box (HMGB)-1 protein to bind metallated 40-base DNA fragments was investigated in a cell-free system by electrophoretic mobility shift assay (EMSA). The modification of the DNA probe with the reference cytotoxic drug cisplatin resulted in the emergence of a more slowly migrating band indicating the specific binding of HMGB-1 to the platinated 40-base DNA fragments [55,56] (Figure 8). As seen on the electrophoregram depicted in Figure 8 of the DNA probe modification with the reference cytotoxic drug cisplatin resulted in the emergence of a more slowly migrating band indicating the specific binding of HMGB-1 to the platinated 40-base DNA fragments. In a dissimilar manner, the Pd1-modified DNA was not recognized as evidenced by the similar mobility of both Pd1-lesioned and untreated DNA probes. Thus it would be expected that the Pd1-modified DNA would not be shielded by the HMGB-1, indicating a further discrepancy in the molecular pharmacology of the presented class of agents vs. the classical cisplatin analogs.

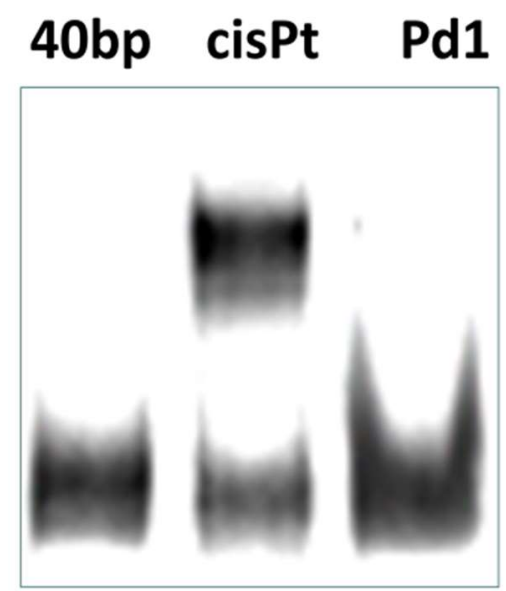

Figure 8. Binding of HMGB-1 protein to DNA-modified by either cisplatin or Pd1 as determined by electrophoretic mobility shift assay (EMSA). DNA:protein molar ratio 1:9. 


\section{Discussion}

In the framework of the design of new antitumor agents, two paramagnetic Pd ${ }^{\mathrm{III}}$-complexes of hematoporphyrin IX were obtained and biologically tested as representatives of the group of cisplatin-dissimilar metal-based coordination compounds. The reaction conditions for their synthesis were chosen to provide obtaining of $\mathrm{Pd}^{3+}$ species [57] and their stabilization in solution and solid state through formation of Hp-complexes [32-35]. The complexes were synthesized during the interaction of an initial $\mathrm{Pd}^{\mathrm{II}}$ compound as a chloride complex $\left(\left[\mathrm{PdCl}_{4}{ }^{2-}\right]\right)$ with the twofold deprotonated at peripheral propionic acid groups hematoporphyrin IX ligand $\left(\left[\mathrm{Hp}_{-2 \mathrm{H}}\right]^{2-}\right)$ in alkaline-aqueous medium achieved by adding $\mathrm{KOH}$. All measurements performed during the interaction manifested that a redoxy process takes place together with the coordination reaction. The large spontaneous increase of the acidity of the reaction system together with the appearance of the EPR signals (Figure 1) proved that the studied process is a very complicated coordination reaction with production of a mixture of paramagnetic metal complexes and stable radicals. The appearance of two-component anisotropic EPR signals with different parameters during the interaction indicates also formation of complex species with different inner coordination sphere of the paramagnetic metal centers. The mode of Hp coordination can be distinguished by using UV/Vis characterization of the reaction system. Coordination via the side deprotonated propionic $\mathrm{COO}^{-}$groups could be supposed because of the hypsochromic shift of the Soret band owing to the porphyrin plane distortion. The spectral changes that follow are most probably connected to a distortion of the porphyrin ring symmetry owing to the coordination through two adjacent pyrrole $\mathrm{N}$-atoms and formation of lower symmetry complex species. The reduction of the Q-bands number to two at the end of the reaction is owing to degeneration of the exited state $S_{1}$ orbitals [58] and proves the formation of a metalloporphyrin type complex ( $\mathrm{D}_{4 \mathrm{~h}}$ symmetry).

Two of the complex species formed during the interaction $\mathrm{PdCl}_{4}{ }^{2-}-\mathrm{Hp}_{-2 \mathrm{H}}$ have been isolated at proper reaction conditions. A dinuclear compound Pd1 was the main product from the interaction at a metal excess ( $\mathrm{Pd}: \mathrm{Hp} \geq 4$ ) and was spontaneously precipitated at $\mathrm{pH} \sim 8$ and a mononuclear metalloporphyrin type complex $\mathbf{P d} \mathbf{2}$ was the main product of the interaction at an equimolar ratio of the reagents and was precipitated by adding hydrochloric acid $\left(5 \times 10^{-2} \mathrm{M} \mathrm{HCl}\right)$. The composition of the complexes was derived from the elemental analyses and the content of $\mathrm{H}_{2} \mathrm{O}$ and $\mathrm{Cl}^{-}$in the inner or the outer coordination sphere was proven by studying their thermal behavior [34]. The molecular structure of the complexes in solid state was deduced based on detailed investigations of their magnetic properties and spectroscopic characterization, published in [34].

A crucial issue in developing a new drug formulation is to study the structure of the compound in solution and to establish the relationship with the solid state structure. The data presented here relate to the behavior of the complexes in DMSO solutions. The low temperature EPR spectra (Figure $4 a, b$ ) of the complexes dissolved in DMSO show characteristic EPR spectral patterns of paramagnetic Pd-compounds. The EPR spectra recorded several hours (5-8 h) after the dissolving correspond well to the solid state EPR spectra [34]. The two anisotropic EPR signals observed in the spectrum of $\mathbf{P d} \mathbf{1}$ possess axial symmetry. The principal values of the g-tensors of the two anisotropic signals $\mathrm{g}_{\mathrm{II}}>\mathrm{g}_{\perp}>2.0023$ are consistent with formation of an elongated octahedral coordination with $\left(\mathrm{dz}^{2}\right)^{1}$-ground state. A five-component superhyperfine structure is observed only in the perpendicular region of the low-field signal. The principal value of the superhyperfine coupling tensor $\mathrm{a}_{\perp}(\mathrm{N})=15.31 \times 10^{-4} \mathrm{~cm}^{-1}\left(\mathrm{I}\left({ }^{14} \mathrm{~N}\right)=1\right)$ and the number of superhyperfine lines typical for interaction of the uncoupled electron with two ${ }^{14} \mathrm{~N}$ nuclei proved coordination of one $\mathrm{Pd}^{3+}$ via two of the pyrrole nitrogen donors of the Hp ligand. The absence of a superhyperfine structure from ${ }^{14} \mathrm{~N}$ nuclei on the upfield EPR signal is due to coordination out of the porphyrin ring through the propionic acid groups. The wide signal observed at $\sim 3050 \mathrm{G}$ could be assigned to exchange singlet-triplet interaction between the two unpaired electrons of the differently coordinated $\mathrm{Pd}^{3+}$-centers in the molecule of Pd1. Hence the EPR spectra proved the formation of a Pd ${ }^{3+}-\mathrm{L}-\mathrm{Pd}^{3+}$ system where each of the $\mathrm{Pd}$-ions possesses different coordination. The presence of a signal for a radical could be explained with significant delocalization of the unpaired electron density because of electron-acceptor properties 
and significant flexibility of the porphyrin moiety. The complex Pd2 features a completely different EPR spectrum pattern in solution containing exactly one two-component anisotropic signal. The signal displays axial anisotropy with principal values of the g-tensor $\mathrm{g}_{\perp}>2.0023>\mathrm{g}_{\text {II }}$ proving formation of a compressed octahedral structure with $\left(d x^{2}-y^{2}\right)^{1}$ ground state. Superhyperfine lines were observed both in perpendicular and parallel regions. The principal values of the axially symmetrical superhyperfine coupling tensor are typical for the interaction of an uncoupled electron with ${ }^{14} \mathrm{~N}(\mathrm{I}=1)$ nuclei. The nine superhyperfine lines are readily distinguished in the perpendicular region and prove coordination of $\mathrm{Pd}^{3+}$ into the four pyrrole $\mathrm{N}$-donors in the porphyrin ring. Thus the spectrum confirms the existence of a stable metalloporphyrin type complex in solution.

It is well-known that changes in the conjugation and the symmetry of the Hp-ligand can affect the UV/Vis absorption spectra and can be used to obtain data about the mode of Hp coordination at complex species in solution [32-39]. While the metal binding through inner nitrogen atoms induces strong changes in the visible region of the spectra, the variations in the peripheral substituents causes minor changes owing to geometrical deformation of the porphyrin ring. The UV/Vis spectra were recorded of the studied compounds dissolved in DMSO. It was found that the position of the Soret band is sensitive to the processes such as acid-base equilibria and aggregation, and also to the modes of metal coordination. It is accepted that the Soret band appears at $376 \mathrm{~nm}$ if the propionic acid groups are deprotonated and shifts in accordance with the electronic density distribution caused by protonation and metal-coordination. The major component of the Soret band in the spectrum of the free ligand dissolved in DMSO $(400 \mathrm{~nm}, \lg \varepsilon=5.02)$ is batochromically shifted compared to the spectrum registered in alkaline-aqueous medium. The shoulder observed at $376 \mathrm{~nm}$ is due to the protolitic equilibrium $\mathrm{Hp}+2 \mathrm{Solv} \Leftrightarrow\left[\mathrm{Hp}_{-2 \mathrm{H}}\right]^{2-}+2[\mathrm{HSov}]^{+}$, which is clearly shifted to the neutral Hp molecules in the weakly proton-acceptor solvent DMSO. In the spectra of the complexes this band is observed at $399 \mathrm{~nm}$ (Pd1) and $396 \mathrm{~nm}$ (Pd2), respectively. Thus it indicates that the propionic acid groups are engaged in the processes of coordination or protonation.

The spectrum pattern in the area of Q-bands is determined by the symmetry group of the porphyrin macrocycle. The two diagonally located hydrogen atoms at pyrrolic nitrogens in the molecule of the free ligand define a $\mathrm{D}_{2 \mathrm{~h}}$ symmetry and hence a four number Q-bands spectrum. The loose of a proton gives a monoprotic ligand form. Many metal ions at proper $\mathrm{pH}$ value $(6<\mathrm{pH}<10)$ interact with the monoprotic ligand anion and bind with its two cis-disposed pyrrole $\mathrm{N}$-donors on the top of the macrocycle forming sitting-atop (SAT) complex. The metal in these complexes is located out of the porphyrin plane and distorts it. The symmetry of the structure is lower (approximately between $C_{4 v} \rightarrow C_{1}$ ) than that of both metalloporphyrins $\left(D_{4 h}\right)$ where the two ammine hydrogens are substituted by the metal located coplanar on the porphyrin ring and the free $\mathrm{Hp}$ ligand $\left(\mathrm{D}_{2 \mathrm{~h}}\right)$. This reflects on the Q-bands number reduction and changes their intensities. Hence the observed spectrum of the complex Pd1 in the area of Q-bands containing mainly three Q-bands $(507,546$, and $567 \mathrm{~nm}$ ) with intensity IV III > II is consistent with coordination through the two cis-disposed pyrrole $\mathrm{N}$-donors on the top of the porphyrin macrocycle substituting one of the pyrrolic nitrogen. Further on, the slight red shift of the Q-bands: IV and III and a blue shift of the Q band II with degeneration of the $Q_{x}$ and $Q_{y}$ orbitals connected with vibronic structure supports simultaneous coordination on the top of the porphyrin ring and out-side the porphyrin macrocycle through the peripheral deprotonated carboxylic groups. The typical two Q-band spectrum of the complex Pd2 indicates unambiguously a $\mathrm{D}_{4 \mathrm{~h}}$ symmetry achieved at coordination through the four $N$-heteronuclei in the porphyrin macrocycle. The intensive bands at $270(\lg \varepsilon=4.98)$ and $323 \mathrm{~nm}(\lg \varepsilon=4.81)$ in the spectrum of Pd1 as well as the one at $280(\lg \varepsilon=3.99)$ in the spectrum of $\mathbf{P d} 2$ were assigned to the ligand-to-metal charge transfer bands of the $\mathrm{Pd}-\mathrm{Cl}$ bonds. This proves the presence of $\mathrm{Cl}^{-}$ions in the palladium ions inner coordination sphere.

The spectroscopic characteristics observed were unchangeable within more than five days. Hence in this period the compounds, dissolved in DMSO solution are paramagnetic palladiumhematoporphyrin IX complexes as follows: (1) for Pd1—a dinuclear Pd-Hp-Pd system, with two 
$\mathrm{Pd}^{\mathrm{III}}$ ions that occupied two coordination places—at the porphyrin ring binding out-of-plan through two cis-disposed N-donors and at the two peripheral propionic acid groups; (2) for Pd2-normal metalloporphyrin of $\mathrm{Pd}^{\mathrm{III}}$. Furthermote, this is the reason to accept that during the biological investigation the active species in solution are these palladium complexes of hematoporphyrin IX.

The cytotoxic screening of the two palladium(III) complexes was conducted on a wide spectrum of cell lines-representatives of the main human cancer types. The results of the MTT-dye reduction assay $[50,51]$ unambiguously indicate that the two compounds exert concentration-dependent antiproliferative effects against the chosen spectrum of cell lines. Data analysis shows that the tested palladium compounds are generally less active than cisplatin, causing half-maximal inhibition of cell viability at generally higher concentrations (Table 1). It has also been proven that the dinuclear palladium complex Pd1 demonstrates superior activity as compared to the metalloporphyrin type complex Pd2. The latter Pd2 compound exerts only marginal activity and fails to cause 50\% inhibition of malignant cell growth against a half of the cell lines under evaluation. Throughout the panel investigated the anticancer drug cisplatin proved to outclass the novel palladium complexes, with the only exception of K-562 leukemia whereby Pd1 showed remarkable cytotoxicity [34].

These findings gave us a reason to conduct more detailed pharmacodynamic evaluation of Pd1 especially regarding its ability to induce apoptosis and to modify DNA. Significant apoptotic fragmentation of genomic DNA was established after treatment of HL-60 cells with both cisplatin and Pd1, whereby the proapoptotic effect of Pd1 required the cell exposure to concentrations significantly higher than its $\mathrm{IC}_{50}$. These data indicate that the cytotoxicity of both compounds is mediated by induction of apoptosis, although its threshold level was significantly higher for the palladium compound.

Further experiments were carried out in order to characterize the adduct-forming ability of Pd1 and the cellular processing of the DNA-lesions. The N7 position of guanine is considered as the ultimate pharmacological target of platinum drugs, leading to formation of intrastrand adducts whose recognition and processing leads to activation of the cell death signaling pathways $[59,60]$. On this ground we studied the metallation of a single strand 40-base DNA fragment in a cell free system. The palladium compound Pd1 was less capable of forming DNA adducts under the experimental conditions, thus further demonstrating its cisplatin-dissimilar pharmacological properties. These findings indicate that although the DNA-modification plays an important role for the mode of antiproliferative action of Pd1; its capacity to modify DNA is lower as compared to that of cisplatin.

The structural perturbations induced by the DNA-metallation are recognized by diverse proteins including the DNA-repair enzymatic machinery $[59,61,62]$. Removal of platinum-DNA adducts by the nucleotide excision repair (NER) is one of the crucial mechanisms of cellular resistance to cisplatin. This prompted us to evaluate the efficiency of NER repair synthesis after modification of pBS plasmids with either cisplatin or Pd1. The lesions induced by cisplatin were far better recognized and repaired as compared to those of Pd1, implying that, by virtue of the significant structural differences between the tested complexes, they induce highly dissimilar alterations of DNA conformation. The lower level of NER-mediated removal and repair of Pd1 modified DNA are an advantageous future of the novel compound as this would condition retained activity against malignant cells overexpressing the NER-enzymatic system.

Apart from the DNA-repair enzymes other proteins are also capable of recognizing and binding cisplatin-modified DNA $[59,61,63]$. Among these special attention has been paid to the high mobility group domain (HMG) proteins $[55,59,61,64]$. They are considered to play crucial role for the cytotoxicity of platinum drugs, whereby the proposed mechanisms include: (i) shielding of platinated DNA and steric hindrance against NER-mediated repair of metal-adducts; (ii) "hijacking" i.e., binding of transcription factors or other regulatory proteins to HMG-associated platinum adducts, thus deviating them from their normal targets and compromising their role in signal transduction $[59,61,63]$. On this ground we evaluated the recognition and binding of HMGB-1 protein to cisplatin or Pd1 modified DNA probes. As made evident by the results obtained Pd1-induced modification conditions lower 
level of HMGB-1 binding, as compared to cisplatin-lesioned DNA. This implies that the high mobility group proteins are most probably less involved in the cytotoxicity of the palladium agent.

\section{Materials and Methods}

\subsection{Chemicals and Tested Compounds}

All chemicals used were of analytical grade and were obtained by commercial sources and used without further purification. Agarose, ethanol, DMSO, formic acid, 2-propanol, methanol, EDTA, ethidium bromide, sodium chloride, Tris hydrochloride, Triton ${ }^{\circledR}$ X-100, L-glutamine were purchased from AppliChem GmbH, Darmstadt, Germany. The tetrazolium salt 3-(4,5-dimethylthiazol-2-yl)-2,5diphenyltetrazolium bromide (MTT) and TE buffer were supplied by Merck, Darmstadt, Germany. Fetal calf serum (FCS), powdered RPMI 1640 medium, the amino acid, sodium pyruvate, human insulin, and polyacrylamide gel were purchased from Sigma-Aldrich $\mathrm{GmbH}$, Steinheim, Germany. The referent cytotoxic drug cis-DDP was used as a commercially available sterile dosage form for clinical application (Platidiam ${ }^{\circledR}$, Lachema, Czech Republic). The two complexes tested, namely: cis- $\left[\mathrm{Pd}_{2}^{\mathrm{III}}{ }_{2}\left(\mathrm{Hp}_{-3 \mathrm{H}}\right) \mathrm{Cl}_{3}\left(\mathrm{H}_{2} \mathrm{O}\right)_{5}\right] \cdot 2 \mathrm{PdCl}_{2}(\mathbf{P d} 1)$ and, $\left[\mathrm{Pd}^{\mathrm{III}}\left(\mathrm{Hp}_{-2 \mathrm{H}}\right) \mathrm{Cl}\left(\mathrm{H}_{2} \mathrm{O}\right)\right] \cdot \mathrm{H}_{2} \mathrm{O}(\mathbf{P d} 2)$ were synthesized, characterized and purified as previously described [34]. UV-Visible (UV-Vis) (solv. DMSO) $\lambda_{\max } / \mathrm{nm}$, (loge): complex Pd1: 270 (4.98), 323 (4.81), 399 (5.02), 507 (3.68), 546 (3.68), 567 (3.63); complex Pd2: 280 (3.99), 396 (4.91), 512 (3.58), 548 (3.74).

\subsection{Solution Stability Assays}

The absorption electronic spectra were recorded on a "Carry" 100 UV-Vis spectrometer. The EPR spectra were obtained on an X-band "Bruker B-EPR 420" spectrometer at $130 \mathrm{~K}$. The UV-Vis and EPR spectra were measured after dissolving the Pd-complexes samples in DMSO within the concentration intervals of $\left(5 \times 10^{-6}\right) \div\left(1 \times 10^{-4}\right) \mathrm{mol} / \mathrm{L}$ for UV-Vis spectra and $5 \times 10^{-4}-5 \times 10^{-3} \mathrm{~mol} / \mathrm{L}$ for EPR spectra, respectively.

\subsection{Cell Lines and Culture Conditions}

In this study the following cell lines were used: SKW3 (T-cell leukemia), K-562 and LAMA-84 (chronic myeloid leukemia), HL-60 (acute myelocyte leukemia), HD-MY-Z (Hodgkin lymphoma), 5637, EJ (urinary bladder carcinomas), and MCF-7 (mammary gland adenocarcinoma). The cells were maintained in controlled environment-cell culture flasks at $37^{\circ} \mathrm{C}$ in an incubator 'BB 16-Function Line' Heraeus (Kendro, Hanau, Germany) with humidified atmosphere and $5 \% \mathrm{CO}_{2}$. They were kept in log phase by supplementing with fresh medium, two or three times a week. SKW3, K-562, LAMA-84, HL-60, HD-MY-Z, 5637, and EJ cells were grown in RPMI-1640 medium supplemented with $10 \%$ fetal bovine serum (FBS) and $2 \mathrm{mM}$ L-glutamine. MCF-7 cells were grown as monolayer adherent cultures in 90\% RPMI-1640 supplemented with 10\% FBS, non-essential amino acids, $1 \mathrm{mM}$ sodium pyruvate, and $10 \mathrm{mg} / \mathrm{mL}$ human insulin.

\subsection{MTT-Dye Reduction Assay}

The tumor cell growth inhibitory effects were assessed using the standard 3-[4-dimethylthiazol2-yl]-2,5-diphenyl-2H-tetrazolium bromide (MTT)-dye reduction assay as described by Mosmann [50] with minor modifications [51]. Exponentially growing cells were seeded in 96-well flat-bottomed microplates $(100 \mu \mathrm{L} /$ well $)$ at a density of $1 \times 10^{5}$ cells per $\mathrm{mL}$ and after $24 \mathrm{~h}$ incubation at $37^{\circ} \mathrm{C}$ they were exposed to various concentrations of the tested compounds for $72 \mathrm{~h}$. At least 8 wells were used for each concentration. After incubation with the tested compounds $10 \mu \mathrm{L}$ MTT solution $(10 \mathrm{mg} / \mathrm{mL}$ in PBS) aliquots per well were added. The microplates were further incubated for $4 \mathrm{~h}$ at $37^{\circ} \mathrm{C}$ and the MTT-formazan crystals formed were dissolved by adding $100 \mu \mathrm{L} /$ well $5 \%$ formic acid (in 2-propanol). The absorption was measured using a microprocessor controlled microplate reader (Labexim LMR1) at $580 \mathrm{~nm}$. The cell survival data were normalized to percentage of the untreated control and were fitted 
to sigmoidal dose/response curves. The corresponding $\mathrm{IC}_{50}$ values were calculated using non-linear regression analysis.

\subsection{Apoptosis Assay}

The typical apoptosis oligonucleosomal DNA fragmentation was examined using a commercially available "Cell-death detection" ELISA kit (Roche Applied Science, Mannheim, Germany). Cytosolic fractions of $1 \times 10^{4}$ cells per group (treated or untreated) served as antigen source in a sandwich ELISA, utilizing primary anti-histone antibody-coated microplate and a secondary peroxidase-conjugated anti-DNA antibody. The photometric immunoassay for histone-associated DNA fragments was executed according to the manufacturer's instructions. The results are expressed as the oligonucleosome enrichment factor (representing a ratio between the absorption in the treated vs. the untreated control samples).

\subsection{DNA-Binding}

The DNA binding of the dinuclear palladium agent and cisplatin was assessed as previously described [52]. A 40 n.b. fragment (5' CGCTATCGCTACCTATTGGATCCTTATGCGTTAGTGTA TG $\left.3^{\prime}\right)$, whereby the GG-motif is the recognition sequence of the restriction nuclease BamH1 was used as a target DNA molecule. The level of DNA modification following interactions between the tested complex and the 40 n.b. fragment was analyzed after BamH1 treatment, electrophoretic analysis in $5 \%$ native polyacrylamide gel, and ethidium bromide staining, as previously described [52].

\subsection{In Vitro DNA Repair}

Synthetic pBS plasmids $(2.69 \mathrm{~kb})$ served as a DNA probe in this study. They were propagated in Escherichia coli and extensively purified as closed circular DNA by means of a FlexiPrep Kit (Pharmacia Biotech, Uppsala, Sweden). Modification of plasmid DNA $(200 \mu \mathrm{g} / \mathrm{mL})$ with the tested palladium complex or cisplatin was carried out in TE buffer (10 mM Tris, $1 \mathrm{mM}$ EDTA), $\mathrm{pH}=7.4$, in the dark at $37^{\circ} \mathrm{C}$ for $16 \mathrm{~h}$. Following ethanol precipitation, DNA was washed twice in $70 \%$ ethanol and redissolved in TE buffer, and the superhelical form of the plasmid DNA was purified by ethidium bromide/cesium chloride gradient centrifugation. Cell-free extract (CFE) from exponentially growing Guerin ascites tumor cells was prepared using a previously described protocol [53], adapted for in vitro DNA repair studies [54] and stored at $-80{ }^{\circ} \mathrm{C}$ until use. Repair of DNA lesions induced by the metal complexes was assayed as described elsewhere [52]. Briefly, the standard $50 \mu \mathrm{L}$ reaction mixture contained $400 \mathrm{ng}$ of metal complex-treated repair substrate pBS, $400 \mathrm{ng}, 45 \mathrm{mM}$ HEPES-KOH, $\mathrm{pH}=7.8,70 \mathrm{mM} \mathrm{KCl}, 5 \mathrm{mM} \mathrm{MgCl} 2,1 \mathrm{mM}$ dithiothreitol, $0.4 \mathrm{mM}$ EDTA, $2 \mathrm{mM}$ ATP, $20 \mu \mathrm{M}$ each of dTTP, dGTP, dATP, $2 \mu \mathrm{Ci}\left[{ }^{32} \mathrm{P}\right] \mathrm{dCTP}$ (Amersham, 3000Ci/mmol, Amersham Bioscinces, Freiburg, Germany), $40 \mathrm{mM}$ phosphocreatine, $2.5 \mu \mathrm{g}$ of creatine phosphokinase, $3 \%$ glycerol, $20 \mu \mathrm{g}$ of bovine serum albumin, and $80-120 \mu \mathrm{g}$ of cell-free extract at $30^{\circ} \mathrm{C}$ for $1 \mathrm{~h}$. Reactions were stopped by adding EDTA to $20 \mathrm{mM}$, and mixtures were incubated for $20 \mathrm{~min}$ with RNase A $(80 \mu \mathrm{g} / \mathrm{mL})$ followed by another $20 \mathrm{~min}$ with proteinase $\mathrm{K}(200 \mu \mathrm{g} / \mathrm{mL})$ in the presence of $0.5 \%$ SDS. Plasmid DNA was purified with phenol/chloroform (1:1) and precipitated by 2 vol of ethanol in the presence of glycogen (Stratagene, La Jolla, CA, USA, $1 \mathrm{mg} / \mathrm{mL}$ ) at $-70{ }^{\circ} \mathrm{C}$. Thereafter the plasmids were linearized by digestion with EcoRI and resolved by electrophoresis in $0.8 \%$ agarose gel containing ethidium bromide $(0.5 \mu \mathrm{g} / \mathrm{mL})$. After electrophoresis, the gel was photographed under UV illumination, dried under vacuum, and exposed to Kodak XAR- 5 film for $12 \mathrm{~h}$ at $-70^{\circ} \mathrm{C}$. The autoradiograph was scanned with Gel-Pro Analyser (Media Cybernetics, Bethesda, MD, USA).

\subsection{Electrophoretic Mobility Shift Assay (EMSA)}

DNA binding assay of HMGB-1 and its truncated form with ${ }^{32} \mathrm{P}$-labeled cisplatinated DNA was performed as described previously [55]. In brief, nonlabeled sonicated salmon sperm DNA was added as a competitor in all experiments except those designed to determine the dissociation 
constants. On completion of electrophoresis the gel was dried and exposed to Amersham hyperfilm. Quantification of band densities was performed by scanning the autoradiographs with Gel-Pro Analyzer. In some assays, the reaction mixture prepared for EMSA was supplemented with CFE preincubated with nonplatinated DNA (500-fold molar excess over the platinated probe) and loaded on the gel. Isolation and purification of recombinant HMGB-1 were carried out as described elsewhere [56].

\section{Conclusions}

Two newer members of the group of paramagnetic transition metal complexes of hematoporhyrin IX [32-39] have been proposed for extended biological screening: a dinuclear $\left[\mathrm{Pd}_{2}{ }_{2}\left(\mathrm{Hp}_{-3 \mathrm{H}}\right) \mathrm{Cl}_{3}\left(\mathrm{H}_{2} \mathrm{O}\right)_{5}\right] \cdot 2 \mathrm{PdCl}_{2}$ and a mononuclear $\left[\mathrm{Pd}^{\mathrm{III}}\left(\mathrm{Hp}_{-2 \mathrm{H}}\right) \mathrm{Cl}\left(\mathrm{H}_{2} \mathrm{O}\right)\right] \cdot \mathrm{H}_{2} \mathrm{O}$. The complexes were obtained reproducibly in alkaline-aqueous medium and were isolated as neutral compounds changing the acidity of the reaction system and the M:L molar ratios. Their structure and stability were studied in DMSO solutions in details. It was found that the active species in solution are a dinuclear complex (Pd1) and a mononuclear (Pd2) complex. In the dinuclear complex Pd1, one Pd ${ }^{\mathrm{III}}$ ion is coordinated to the deprotonated $\mathrm{COO}^{-}$groups from the side chains of the porphyrin ligand and the second $\mathrm{Pd}^{\mathrm{III}}$ ion-to two adjacent pyrrole $\mathrm{N}$-atoms on the top of the porphyrin ring and thus a dinuclear Pd ${ }^{\mathrm{III}}-\mathrm{Hp}-\mathrm{Pd}^{\mathrm{III}}$ system is created. $\mathrm{Pd}^{\mathrm{III}}$ in the mononuclear complex, Pd2, is located in the plane of the porphyrin ring and thus a metalloporphyrin type complex is formed. $\mathrm{Pd}^{\mathrm{III}}$ centers in both complexes have a distorted octahedral coordination filled with additional donor species such as $\mathrm{Cl}^{-}$ and solvent molecules.

The compounds tested manifested cell growth inhibitory effects at micromolar concentration against tumor cell lines with distinct cell type and origin. The calculated $\mathrm{IC}_{50}$ values proved that in general, palladium complexes exhibit lower activity compared to that of the referent drug cisplatin and as a rule the metalloporphyrin type complex $\mathbf{P d} 2$ is less active than the dinuclear compound Pd1. Contrarily to the general trend the Pd1 complex exerts remarkable activity against K-562 cells, with $50 \%$ cell growth inhibition at more than 4 -fold lower concentration compared to cisplatin. It also displays relatively close activity against the HD-MY-Z cell line with regard to the referent drug. The palladium complexes' ability to induce programmed cell death was evaluated in a comparative experiment of Pd1 and cisplatin in HL-60 cells. The two compounds cause significant increase in the apoptotic histone-associated DNA fragments. However, the novel dinuclear compound causes comparable proapoptotic effects at substantially higher concentrations and that corresponds to the tumor cell line chemosensitivity bioassay. The parallel evaluation of Pd1 and cisplatin's ability to form intra-strand guanine bis-adducts shows that Pd1 also inhibits the nuclease activity, but failed to totally hamper the fragmentation of the target DNA-molecule. Hence, although the DNA-modification plays an important role for the mode of antiproliferative action of Pd1, its capacity to modify DNA is lower compared to that of cisplatin. The elucidation of DNA-adducts cellular processing by the NER enzymes demonstrated that the lesions induced by cisplatin were far better recognized and repaired as compared to those of Pd1. The lower level of NER-mediated removal and repair of Pd1 modified DNA are an advantageous characteristic of the novel compound and that means that Pd1 would retain the activity against malignant cells, overexpressing the NER-enzymatic system. The ability of HMGB-1 protein to bind metallated 40-base DNA fragment with the reference cytotoxic drug cisplatin resulted in a specific binding. In a dissimilar manner, the Pd1-modified DNA was not recognized and it could be expected that the Pd1-modified DNA would not be shielded by the HMGB-1.

The data analysis of the in-depth biological study unambiguously highlights the differences in molecular pharmacology of the presented "applicants" for antitumor agents in respect to cisplatin. Moreover, the advantages of the new compounds provide grounds for joining them to the "nonclassical metal compounds" group. Their unique structure, based on the octahedral coordination of palladium(III) stabilized with a ligand with favorable properties, is a prerequisite for constructing a new formula with a potential of controlling its kinetic behavior as well as the strength of the M-L bonds of the adducts formed in the biological milieu. 
Author Contributions: Conceptualization, G.G. and G.M.; Methodology, E.P., G.M., D.T., and G.G.; Software, G.M., I.U., and D.T.; Validation, E.P., G.M., and G.G.; Formal Analysis, D.T., I.U., and G.M.; Investigation, G.M., I.U., E.P., D.T., and G.G.; Writing-Original Draft Preparation, G.G. and G.M.; Writing-Review \& Editing, G.G. and D.T.; Supervision, G.G.; Project Administration, G.G. and G.M.

Funding: This research was funded by the National Science Fund (Bulgaria), grant number DN09/16, Bulgarian Ministry of Education and Science, available online: https:/ / www.fni.bg.

Acknowledgments: We gratefully acknowledge the financial support from the National Science Fund (Project DN09/16) of Bulgarian Ministry of Education and Science.

Conflicts of Interest: The authors declare no conflict of interest.

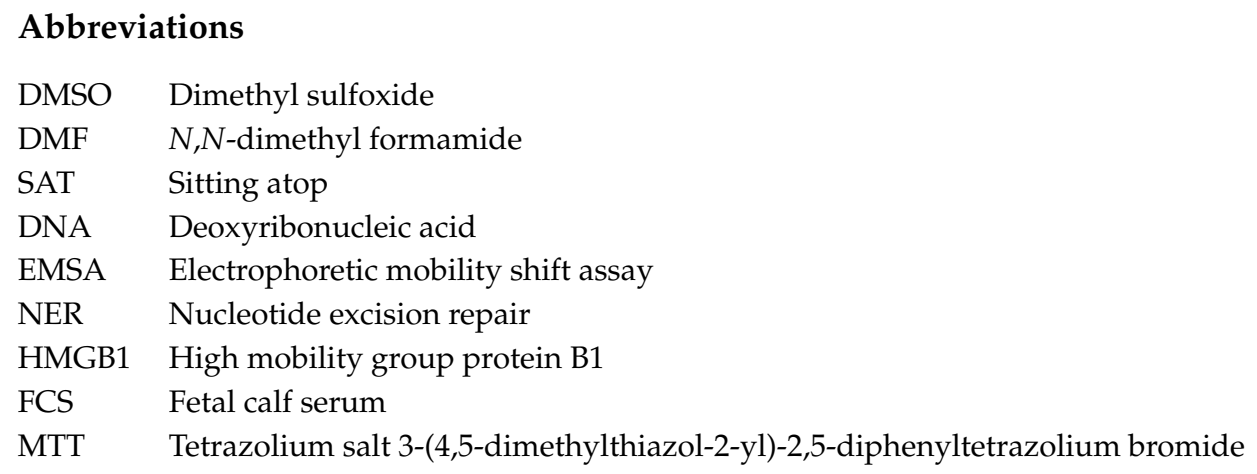

\section{References}

1. Reedijk, J. Increased understanding of platinum anticancer chemistry. Pure Appl. Chem. 2011, 83, $1709-1717$. [CrossRef]

2. Sava, G.; Bergamo, A.; Dyson, P.J. Metal-based antitumour drugs in the post-genomic era: What comes next? Dalton Trans. 2011, 40, 9069-9075. [CrossRef] [PubMed]

3. van Rijt, S.H.; Sadler, P.J. Current applications and future potential for bioinorganic chemistry in the development of anticancer drugs. Drug Discov. Today 2009, 14, 1089-1097. [CrossRef] [PubMed]

4. Allardyce, C.S.; Dyson, P.J. Metal-based drugs that break the rules. Dalton Trans. 2016, 45, 3201-3209. [CrossRef] [PubMed]

5. Rosenberg, B.; VanCamp, L.; Trosko, J.E.; Mansori, V.H. Platinum compounds: A new class of potent antittumour agents. Nature 1969, 222, 385-386. [CrossRef] [PubMed]

6. Rosenberg, B. Platinum complexes for the treatment of cancer: Why the research goes on? In Cisplatin, Chemistry and Biochemistry of a Leading Anticancer Drug, 1st ed.; Lippert, B., Ed.; Wiley-VCN: Weinheim, Germany, 1999; pp. 3-28, ISBN 3-906390-20-9.

7. Cleare, M.J.; Hoeschele, J.D. Studies on the antitumor activity of group VIII transition metal complexes. Part I. Platinum(II) complexes. Bioinorg. Chem. 1972, 2, 187-210. [CrossRef]

8. Desoize, B.; Madoulet, C. Particular aspects of platinum compounds used at present in cancer tretment. Crit. Rev. Oncol. Hematol. 2002, 42, 317-325. [CrossRef]

9. Johnston, T.C.; Suntharalingam, K.; Lippard, S.J. The next generation of platinum drugs: Target Pt(II) agents, nanoparticle delivery and Pt(IV) prodrugs. Chem. Rev. 2016, 116, 3436-3486. [CrossRef] [PubMed]

10. Martin, L.P.; Hamilton, T.C.; Schilder, R.J. Platinum resistance: The role of DNA repair pathways. Clin. Cancer Res. 2008, 14, 1291-1295. [CrossRef] [PubMed]

11. Heffeter, P.; Jungwirth, U.; Jakupec, M.; Hartinger, C.; Galanski, M.; Elbling, L.; Micksche, M.; Keppler, B.; Berger, W. Resestance against novel anticancer metal compounds: Differences and similarities. Drug Resist. Update 2008, 11, 1-16. [CrossRef] [PubMed]

12. Pabla, N.; Dong, Z. Curtailing side effects in chemotherapy: A tale of PKC $\delta$ in cisplatin treatment. Oncotarget 2012, 3, 107-111. [CrossRef] [PubMed]

13. Wang, X.; Guo, Z. Targeting and delivery of platinum-based anticancer drugs. Chem. Soc. Rev. 2013, 42, 202-224. [CrossRef] [PubMed]

14. Johnstone, T.C.; Park, G.Y.; Lippard, S.J. Understanding and improving platinum anticancer drugsPhenanthriplatin. Anticancer Res. 2014, 34, 471-476. [CrossRef] [PubMed] 
15. Wilson, J.J.; Lippard, S.J. Synthetic Methods for the preparation of platinum anticancer complexes. Chem. Rev. 2014, 114, 4470-4495. [CrossRef] [PubMed]

16. Reedijk, J. Metal-ligand exchange kinetics in platinum and ruthenium complexes. Platin. Met. Rev. 2008, 52, 2-11. [CrossRef]

17. Johnstone, T.C.; Wilson, J.J.; Lippard, S.J. Monofunctional and Higher-Valent Platinum Anticancer Agents. Inorg. Chem. 2013, 52, 12234-12249. [CrossRef] [PubMed]

18. Hall, M.D.; Okabe, M.; Shen, D.-W.; Liang, X.-J.; Gottesman, M.M. The role of cellular accumulation in determining sensitivity of platinum-based chemotherapy. Annu. Rev. Pharmacol. Toxicol. 2008, 48, 495-535. [CrossRef] [PubMed]

19. Howell, S.B.; Safaei, R.; Larson, C.A.; Sailor, M.J. Copper transporters and the cellular pharmacology of the platinum-containing cancer drugs. Mol. Pharmacol. 2010, 77, 887-894. [CrossRef] [PubMed]

20. Harrach, S.; Ciarimboli, G. Role of transporters in distribution of platinum-based drugs. Front. Pharmacol. 2015, 6, 1-8. [CrossRef] [PubMed]

21. Dilruba, S.; Kalayda, G.V. Platinum-based drugs: Past, present and future. Cancer Chemother. Pharmacol. 2016, 77, 1103-1124. [CrossRef] [PubMed]

22. Galanski, M.; Jakupec, M.A.; Keppler, B.K. Update of the preclinical situation of anticancer platinum complexes: Novel design strategies and innovative analytical approaches. Curr. Med. Chem. 2005, 12, 2075-2094. [CrossRef] [PubMed]

23. Wang, D.; Lippard, S.J. Cellural processing of platinum anticancer drugs. Nat. Rev. Drug Discov. 2005, 4, 307-320. [CrossRef] [PubMed]

24. Bruijnincx, P.C.A.; Sadler, P.J. New trends for metal complexes with anticancer activity. Curr. Opin. Chem. Biol. 2008, 12, 197-206. [CrossRef] [PubMed]

25. Pages, B.J.; Garbutcheon-Singh, K.B.; Aldrich-Wright, J.R. Platinum Intercalators of DNA as Anticancer Agents. Eur. J. Inorg. Chem. 2017, 1613-1624. [CrossRef]

26. Rademaker-Lakhai, J.M.; van den Bongard, D.; Pluim, D.; Beijnen, J.H.; Schellens, J.H.M. A phase I and pharmacological study with imidazolium-trans-DMSO-imidazole-tetrachlororuthenate, a novel ruthenium anticancer agent. Clin. Cancer Res. 2004, 10, 3717-3727. [CrossRef] [PubMed]

27. Ang, W.H.; Khalaila, I.; Allardyce, C.S.; Juillerat-Jeanneret, L.; Dyson, P.J. Rational design of platinum(IV) compounds to overcome glutathione-S-transferase mediated drug resistance. J. Am. Chem. Soc. 2005, 127, 1382-1383. [CrossRef] [PubMed]

28. Kenny, R.G.; Chuah, S.W.; Crawford, A.; Marmion, C.J. Platinum(IV) prodrugs-A step closer to Ehrlich's vision? Eur. J. Inorg. Chem. 2017, 1596-1612. [CrossRef]

29. Trondl, R.; Heffeter, P.; Kowol, C.R.; Jakupec, M.A.; Berger, W.; Keppler, B.K. NKP-1339, the first ruthenium-based anticancer drug on the edge to clinical application. Chem. Sci. 2014, 5, 2925-2932. [CrossRef]

30. Leijen, S.; Burgers, S.A.; Baas, P.; Pluim, D.; Tibben, M.; van Werkhoven, E.; Alessio, E.; Sava, G.; Beijnen, J.H.; Schellens, J.H. Phase I/II study with ruthenium compound NAMI-A and gemcitabine in patients with non-small cell lung cancer after first line therapy. Investig. New Drugs 2015, 33, 201-214. [CrossRef] [PubMed]

31. Bhargava, A.; Vaishampayan, U.N. Satraplatin: Leading the new generation of oral platinum agents. Expert Opin. Investig. Drugs 2009, 18, 1787-1797. [CrossRef] [PubMed]

32. Gencheva, G.; Tsekova, D.; Gochev, G.; Momekov, G.; Tyueliev, G.; Skumryev, V.; Karaivanova, M.; Bontchev, P.R. Synthesis, structural characterization and cytotoxic activity of novel paramagnetic platinum hematoporphyrin IX complexes: Potent antitumor agents. Met. Based Drugs 2007, 2007. [CrossRef] [PubMed]

33. Momekov, G.; Karaivanova, M.; Ugrinova, I.; Pasheva, E.; Gencheva, G.; Tsekova, D.; Arpadjan, S.; Bontchev, P.R. In vitro pharmacological study of monomeric platinum(III) hematoporphyrin IX complexes. Investig. New Drugs 2011, 29, 742-751. [CrossRef] [PubMed]

34. Tsekova, D.; Gorolomova, P.; Gochev, G.; Skumryev, V.; Momekov, G.; Momekova, D.; Gencheva, G. Synthesis, structure and in vitro cytotoxic studies of novel paramagnetic palladium(III) complexes with hematoporphyrin IX. J. Inorg. Biochem. 2013, 124, 54-62. [CrossRef] [PubMed]

35. Gencheva, G.; Tsekova, D.; Gochev, G.; Mehandjiev, D.; Bontchev, P.R. Monomeric Au(II) complex with hematoporphyrin IX. Inorg. Chem. Commun. 2003, 6, 325-328. [CrossRef] 
36. Momekov, G.; Ferdinandov, D.; Konstantinov, S.; Arpadjan, S.; Tsekova, D.; Gencheva, G.; Bontchev, P.R.; Karaivanova, M. In vitro evaluation of a stable monomeric gold(II) complex with hematoporphyrin IX: Cytotoxicity against tumor kidney cells, cellular accumulation and induction of apoptosis. Bioinorg. Chem. Appl. 2008, 2008. [CrossRef] [PubMed]

37. Tsekova, D.T.; Gencheva, G.G.; Bontchev, P.R. Mode of coordination of the polydentate ligand hematoporphyrin IX with $\mathrm{Pt}(\mathrm{III}), \mathrm{Pd}(\mathrm{III}), \mathrm{Au}(\mathrm{II})$ and $\mathrm{Cu}(\mathrm{II})$. An overview. C. R. Acad. Bulg. Sci. 2008, 61, 731-738. [CrossRef]

38. Tsekova, D.T.; Gochev, G.P.; Gencheva, G.G.; Bontchev, P.R. Magnetic and spectroscopic methods for structural characterization of paramagnetic hematoporphyrin IX complex with $\mathrm{Cu}(\mathrm{II})$. Eurasian J. Anal. Chem. 2008, 3, 79-90.

39. Tsekova, D.; Ilieva, V.; Gencheva, G. An NMR study on the solution behavior of series of hematoporphyrin IX complexes. In Topics in Chemistry and Material Science. Current Issues in Organic Chemistry 2; Nikolava, R.D., Simova, S., Denkova, P., Vayssilov, G.N., Eds.; Heron Press Ltd.: Sofia, Bulgaria, 2011; Volume 5, pp. 52-65, ISBN 1314-0795.

40. Chang, J.-E.; Yoon, I.-S.; Sun, P.-L.; Yi, E.; Jheon, S.; Shim, C.-K. Anticancer efficacy of photodynamic therapy with hematoporphyrin-modified, doxorubicin-loaded nanoparticles in liver cancer. J. Photochem. Photobiol. B Biol. 2014, 140, 49-56. [CrossRef] [PubMed]

41. Lottner, C.; Knuechel, R.; Bernhardt, G.; Brunner, H. Combined chemotherapeutic and photodynamic treatment on human bladder cells by hematoporphyrin-platinum(II) conjugates. Cancer Lett. 2004, 203, 171-180. [CrossRef] [PubMed]

42. Lottner, C.; Bart, K.-C.; Bernhardt, G.; Brunner, H. Soluble tetraarylporphyrin-platinum conjugates as cytotoxic and phototoxic antitumor agents. J. Med. Chem. 2002, 45, 2079-2089. [CrossRef] [PubMed]

43. Lottner, C.; Bart, K.-C.; Bernhardt, G.; Brunner, H. Hematoporphyrin-derived soluble porphyrin-platinum conjugates with combined cytotoxic and phototoxic antitumor activity. J. Med. Chem. 2002, 45, 2064-2078. [CrossRef] [PubMed]

44. Alam, M.N.; Huq, F. Comprehensive review on tumour active palladium compounds and structure-activity relationships. Coord. Chem. Rev. 2016, 316, 36-67. [CrossRef]

45. Fanelli, M.; Formica, M.; Fusi, V.; Giorgi, L.; Micheloni, M.; Paoli, P. New trends in platinum and palladium complexes as antineoplastic agents. Coord. Chem. Rev. 2016, 310, 41-79. [CrossRef]

46. Garoufis, A.; Hadjikakou, S.K.; Hadjiliadis, N. Palladium coordination compounds as anti-viral, anti-fungal, anti-microbial and anti-tumor agents. Coord. Chem. Rev. 2009, 253, 1384-1397. [CrossRef]

47. Garoufis, A.; Hadjikakou, S.K.; Hadjiliadis, N. The use of palladium complexes in medicine. In Metallotherapeutic Drugs and Metal-Based Diagnostic Agents. The Use of Metals in Medicine; Gielen, M., Tiekink, E.R.T., Eds.; Wiley VC: Chichester, UK, 2005; pp. 399-419, ISBN 0-470-86403-6.

48. Lippert, B.; Miguel, P.J.S. Comparing Pt ${ }^{\mathrm{II}}$ - and $\mathrm{Pd}^{\mathrm{II}}$-nucleobase coordination chemistry: Why Pd ${ }^{\mathrm{II}}$ not always is a good substitute for $\mathrm{Pt}^{\mathrm{II}}$. Inorg. Chim. Acta 2017, 472, 207-213. [CrossRef]

49. Valicsek, Z.; Horváth, O. Application of the electronic spectra of porphyrins for analytical purposes: The effects of metal ions and structural distortions. Microchem. J. 2013, 107, 47-62. [CrossRef]

50. Mosmann, T. Rapid colorimetric assay for cellular growth and survival: Application to proliferation and cytotoxicity assays. J. Immunol. Methods 1983, 65, 55-63. [CrossRef]

51. Konstantinov, S.M.; Eibl, H.; Berger, M.R. BCR-ABL influences the antileukaemic efficacy of alkylphosphocholines. Br. J. Haematol. 1999, 107, 365-374. [CrossRef] [PubMed]

52. Mitkova, E.; Ugrinova, I.; Pashev, I.; Pasheva, E.A. The inhibitory effect of HMGB-1 protein on the repair of cisplatin-damaged DNA is accomplished through the acidic domain. Biochemistry 2005, 44, 5893-5898. [CrossRef] [PubMed]

53. Li, L.; Liu, X.; Glassmann, A.B.; Keating, M.J.; Stros, M.; Plunkett, W.; Yang, L.-Y. Fludarabine triphosphate inhibits nucleotide excision repair of cisplatin-induced DNA adducts in Vitro. Cancer Res. 1997, 57, 1487-1494. [PubMed]

54. Biade, S.; Sobol, R.W.; Wilson, S.H.; Matsumoto, Y. Impairment of proliferating cell nuclear antigen-dependent apurinic/apyrimidinic site repair on linear DNA. J. Biol. Chem. 1998, 273, 898-902. [CrossRef] [PubMed]

55. Pasheva, E.A.; Pashev, I.G.; Favre, A. Preferential binding of high mobility group 1 protein to UV-damaged DNA. Role of the COOH-terminal domain. J. Biol. Chem. 1998, 273, 24730-24736. [CrossRef] [PubMed] 
56. Pasheva, E.; Sarov, M.; Bidjekov, K.; Ugrinova, I.; Sang, B.; Linder, H.; Pashev, I.G. In vitro acetylation of HMGB-1 and -2 proteins by CBP: The role of the acidic tail. Biochemistry 2004, 43, 2935-2940. [CrossRef] [PubMed]

57. Mincheva, N.; Gencheva, G.; Mitewa, M.; Gochev, G.; Mehandjiev, D. Synthesis of new monomeric Pd(III) and dimeric (Pd(III),Pd(II)) complexes with biuret formed in basic medium. Synth. React. Inorg. Met.-Org. Chem. 1997, 27, 1191-1203. [CrossRef]

58. Čunderlíková, B.; Bjørklund, E.G.; Pettersen, E.O.; Moan, J. pH-Dependent spectral properties of HpIX, TPPS $_{2 \mathrm{a}}, m$ THPP and $m$ THPC. Photochem. Photobiol. 2001, 74, 246-252. [CrossRef]

59. Brabec, V.; Kasparkova, J. Platinum-based drugs. In Metallotherapeutic Drugs and Metal-Based Diagnostic Agents; Gielen, M., Tiekink, E.R.T., Eds.; Wiley VC: Chichester, UK, 2005; pp. 489-506, ISBN 0-470-86403-6.

60. Boulikas, T.; Vougiouka, M. Cisplatin and platinum drugs at the molecular level. Oncol. Rep. 2003, 10, 1663-1682. [CrossRef] [PubMed]

61. Brabec, V.; Kasparkova, J. Modification of DNA by platinum complexes. Relation to resistance of tumors to platinum antitumor drugs. Drug Resist. Update 2005, 8, 131-146. [CrossRef] [PubMed]

62. Woźniak, K.; Błasiak, J. Recognition and repair of DNA-cisplatin adducts. Acta Biochim. Pol. 2002, 49, 583-596. [PubMed]

63. Desoize, B. Metals and metal compounds in cancer treatment. Anticancer Res. 2004, 24, 1529-1544. [PubMed]

64. Chabner, B.A.; Amrein, P.C.; Druker, B.J.; Michaelson, M.D.; Mitsiades, C.S.; Goss, P.E.; Ryan, D.P.; Ramachandra, S.; Richardson, P.G.; Supko, J.G.; et al. Chemotherapy of neoplastic disease. In Goodman $\mathcal{E}$ Gilman's the Pharmacological Basis of Therapeutics, 11th ed.; Brunton, L.L., Lazo, J.S., Parker, K.L., Eds.; McGraw Hill: New York, NY, USA, 2006; pp. 1315-1403, ISBN 0-07-160891-5.

(C) 2018 by the authors. Licensee MDPI, Basel, Switzerland. This article is an open access article distributed under the terms and conditions of the Creative Commons Attribution (CC BY) license (http:/ / creativecommons.org/licenses/by/4.0/). 